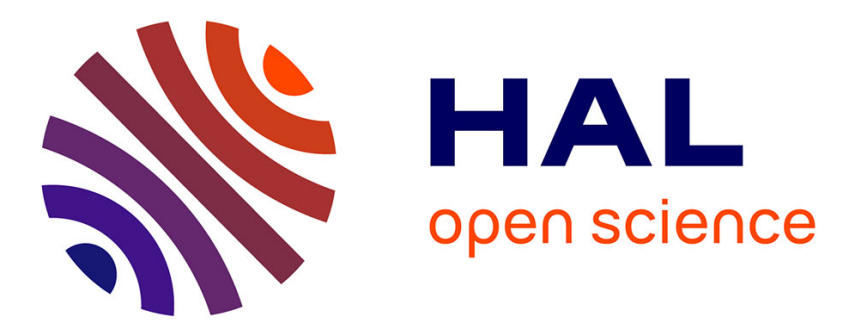

\title{
When tense and aspect convey modality. Reflections on the modal uses of past tenses in Romance and Germanic languages
}

Adeline Patard

\section{- To cite this version:}

Adeline Patard. When tense and aspect convey modality. Reflections on the modal uses of past tenses in Romance and Germanic languages. Journal of Pragmatics, 2014, 71, pp.69-97. 10.1016/j.pragma.2014.06.009 . hal-01700562

\section{HAL Id: hal-01700562 \\ https://hal.science/hal-01700562}

Submitted on 4 Feb 2018

HAL is a multi-disciplinary open access archive for the deposit and dissemination of scientific research documents, whether they are published or not. The documents may come from teaching and research institutions in France or abroad, or from public or private research centers.
L'archive ouverte pluridisciplinaire HAL, est destinée au dépôt et à la diffusion de documents scientifiques de niveau recherche, publiés ou non, émanant des établissements d'enseignement et de recherche français ou étrangers, des laboratoires publics ou privés. 


\title{
When tense and aspect convey modality. Reflections on the modal uses of past tenses in Romance and Germanic languages*
}

Adeline Patard

\begin{abstract}
This paper investigates the connection between past tense and modality in six Romance and Germanic languages (French, Italian, Spanish, Dutch, English and German). I first argue for an aspecto-temporal definition of imperfects and preterits based on the notion of 'reference point' $(\mathrm{R})$ and I suggest that the different interpretations of past tenses (including the modal ones) reflect specific instantiations of $\mathrm{R}$ as 'topic time', 'aspectual vantage point' or 'epistemic evaluation'. Second, I offer a classification and analysis of the modal uses of the imperfects and preterits observed in the languages under investigation. Finally, I expand on the idea that the modal interpretations of past tenses correspond to pragmatic inferences that are being conventionalised and mirror the stages of 'bridging contexts' and 'switch contexts' described in Heine's (2002) model for semantic change.
\end{abstract}

\section{Keywords}

past tense; aspect; modality; semantics; reference point; epistemic evaluation point; Romance languages; Germanic languages; conventionalisation of inference; bridging contexts; switch contexts; scalar implicatures

\section{Introduction}

It is a well-known fact that past tenses may convey modal meanings in a number of languages ${ }^{1}$ (see e.g. James 1982, Comrie 1985, Palmer 1986, Fleischman 1989, Thieroff 1999, Iatridou 2000, Ippolito 2003, Van linden and Verstraete 2008). In examples (1) to (6), the speaker uses a past tense to express attitudinal subjectivity (ex. (1), (3), (5)) or an interpersonal relation with respect to the hearer (ex. (2), (4), (6)).

Counterfactuality

Fre Une seconde de plus $\quad$ [le taureau] l'
one second the bull hore him
'One more second and the bull would have gored him.'
(G. Flaubert, Un cour simple)

Hypocoristic attitude

(2) Ita

$\begin{array}{llll}\text { Aveva } & \text { fame } & \text { la mia } & \text { bambina? } \\ \text { have-PST.IPFV } & \text { hunger } & \text { my } & \text { girl } \\ \text { 'Is my baby hungry?' (Bazanella 1990) } & \end{array}$

Hypothesis $^{2}$

(3) Spa

$\begin{array}{lccll}\text { Si tuviera } & \text { dinero, } & \text { me } & \text { compraba } & \text { una } \\ \text { If have-SBJV.IPFV } & \text { money } & \text { me } & \text { buy-PST.IPFV a } \\ \text { 'If I had money, I would buy me a motorbike.' (Briz Gómez 2004) }\end{array}$

éventrait. gore-PST.IPFV

(G. Flaubert, Un cour simple)

'If Thad money, I would buy me a motorbike.' (Briz Gómez 2004)

\footnotetext{
*The research carried out for this paper has been financed by a Marie Curie IEF fellowship granted by the European Commission (Project AMITy, FP7). I wish to thank the anonymous reviewers for their useful comments and criticisms; they greatly contributed to improve the quality of the paper. All remaining errors are mine.
} 
Politeness

(4) Dut

$\begin{array}{llccc}\text { Had } & \text { mevrouw } & \text { nog } & \text { iets } & \text { gewenst } \\ \text { have-PRF.PST } & \text { madam } & \text { still } & \text { something } & \text { wish-PRF.PST } \\ \text { 'Madam, would you like something else' (A.M. Oster, } & \text { Hoe moet je kijken) }\end{array}$

Wish

(5) Eng I wish I was a punk rocker with flowers in my hair (S. Thom)

Mitigation

(6) Ger

$\begin{array}{llllll}\text { Ger Ich dachte, wirkönnten uns nachmittags } & \text { in der } & \text { Stadt treffen (...). } \\ & \text { I think-PST we could us afternoon } & \text { in the town meet }\end{array}$

'I thought we could meet in town this afternoon'

(F. C. Zöld, Trotzdem liebe ich dich)

Another frequent observation (e.g. James 1982, Fleischman 1995, Boogaart and Trnavac 2011) is that these modal interpretations are typically conveyed by imperfective tenses as in examples (1)-(3), even though simple pasts may also be associated with modality (see examples (4)-(6)). These two observations have yielded a long-standing debate on the origin of modality in such uses, which I briefly sketch in the following paragraphs.

Most of the proposed accounts have been concentrating on the role of tense, advocating a direct connection between past and modality, even though there is no clear consensus on the nature of this connection. The first and most famous explanation posits a metaphorical link between temporality and modality in terms of 'temporal distance' or 'remoteness' (see Imbs 1960, Lyons 1977, James 1982, Vairel 1982, Fleischman 1989): according to this hypothesis, the deictic distance from the speaker's now denoted by past tenses is metaphorically exploited to convey a 'modal distance', i.e., the 'nonreality' or 'low certainty' of the described eventuality. More or less explicitly in opposition to the metaphor analysis, a great number of studies have suggested an alternative explanation, based on an epistemic definition of the past tense as expressing a reality judgment of the speaker (Langacker 1978, 1991; Cutrer 1994; Palmer 1986; Le Goffic 1986, 1995; Thieroff 1994, 1995; Adam 1995; Touratier 1996; Janssen 1994; Caudal et al. 2003; Jaszczolt and Srioutai 2011). Within this view, past tense morphology does not encode past location as a core meaning, but rather denotes a more abstract relation, namely the exclusion of the eventuality from the speaker's immediate 'reality' or 'actuality'. Accordingly, the temporal or modal readings of past tenses constitute specific instantiations of this core epistemic value, which are pragmatically elaborated by means of contextual information (e.g. the import of 'space-builders' in the case of modal uses, cf. Fauconnier 1994 or Dancygier and Sweetser 2005). Dahl (1997) suggests a different connection between past tense and modality, advancing that the core meaning of past tenses is temporal and that modality is a derived interpretation. For Dahl, the semantic contribution of past morphology in counterfactual contexts is to refer to a past 'choice point', that is, the point in time where "the choice between what actually happened and what could have happened is made" (p. 107). Another analysis is proposed by Arregui $(2005,2009)$ for the use of the simple past in hypothetical conditionals. For her, the past morphology in the if-clause is a case of agreement-morphology similar to the standard case of sequence-of-tenses. From this perspective, the past tense occurring in the if-clause is semantically vacuous and only 'copies' the past morphology of the would-clause, which contains the 'real' past tense (the past modal would). ${ }^{3}$

The temporalist approach focusing on the role of tense (whether conceived of epistemically or temporally) tends to obscure the fact that grammatical aspect is also a parameter that determines the modal interpretation, as suggested by the following French example: 


Fre Un pas de plus et elle tombait(tomba).
one step of more and she fall-PST.IPFV /-PST.PFV
'One step further and she would have fallen / fell'.'

The contrast between the past imperfective -ait and the past perfective $-a$ is mirrored in their respective interpretations, which is counterfactual with the imperfect tense and factual with the past perfective tense.

To explain these facts, more and more linguists now include the aspectual dimension in their accounts and aim at shedding light on the correlation between imperfective aspect and modality ${ }^{4}$, along with the contribution of past tense that may be conceived of as either deictic (Mellet 1988, 1990; Martin 1991; Fleischman 1995; Gosselin 1999; , Ippolito 2003; Barceló and Bres 2006; Patard 2007, 2011; Schmid 2010; Boogaart and Trnavac 2011; Caudal 2011; Patard and Richard 2011) or epistemic (Iatridou 2000, Doiz-Bienzobas 2002; De Mulder 2004; De Mulder and Brisard 2006; Brisard 2010). But, again, the analyses tend to differ according to the conception of tense that is adopted. On the epistemic view developed in the framework of Cognitive Grammar (Langacker 1991), imperfects refer to the internal viewpoint of a conceptualizer distinct from the speaker and assumed to be 'virtual' ${ }^{5}$ The virtual viewpoint may then license modal readings when contextual indications specify that the viewpoint has been shifted to a space that is also virtual (e.g. hypothetical, unreal, etc.). On the deictic view, the metaphorical explanation is almost totally abandoned (except in Fleischman 1995), and the link between imperfectivity and modality is treated in two different (but not mutually exclusive) ways. A first set of accounts echoes Hopper's work (1979) and emphasizes the fact that backgrounded eventualities that are viewed imperfectively show a 'lesser degree of assertiveness' (Hopper 1979:216), thus allowing the rise of modal implicatures (Mellet 1988, 1990; Fleischman 1995; Ziegeler 2000; Ippolito 2003 and 2004; Barceló and Bres 2006; Schmid 2010; Patard and Richard 2011). Other analyses point out that, in some contexts (e.g. conditionals), past tense and imperfective aspect have a proposition-external scope: they do not serve to describe the eventuality itself, but refer to the modal evaluation or 'enunciation' of the proposition (Martin 1991; Gosselin 1999; Barceló and Bres 2006; Caudal 2011; Patard 2011). This proposition-external scope is manifested by the fact that imperfective and past morphology is 'fake', 'neutralised' or 'inhibited' in these particular contexts (Squartini 1995, 2001; Iatridou 2000; Caudal et al. 2003), i.e., it is compatible with non-past and perfective interpretations of the eventuality, which should normally be conflicting with it. Example (8) offers an illustration of a modally-used imperfect with a perfective interpretation:

$\begin{array}{llllrll}\text { Fre } & \text { Je } & \text { souffrirais } & \text { trop } & / \text { si } & \text { th } & \text { revenais } \\ & \text { I } & \text { would suffer } & \text { too much } & \text { if } & \text { you } & \text { come back-PST.IPFV } \\ & \text { 'I would suffer too much, if you came back' (Cl. François) }\end{array}$

Here the supposed return of the hearer denoted by revenais ('come back') is seen as completed, otherwise it could not cause the speaker's suffering described in the apodosis.

This recent focus on the aspectual parameter enables a better understanding of the connection between the semantics of imperfect tenses and their affinity with modal effects. However, multiple questions remain unanswered, for instance, why tenses that are aspectually neutral, such as the English simple past, may also receive modal readings (cf. examples (4)-(5)) and whether these aspectually neutral forms entail the same modal effects as the ones generated by imperfects.

As this brief overview shows, various types of explanations have been proposed for the modal uses of past tenses. However, there seems to be a consensus on the following fact: both tense and aspect contribute to modality, even though the contribution of both still needs to be clarified. To bring new 
elements to the discussion and shed a new light on this issue, I adopt a more comprehensive view on the relation between tense, aspect and modality. To that purpose, I choose not to restrict the study to one language or one particular construction, but to consider the whole body of the modal uses attested in six languages (Dutch, English, French, German, Italian and Spanish). The chosen languages belong to two language families, the Romance and the Germanic languages, in which the modally-interpreted past tenses possess different aspectual values. In the Romance languages, the modally-used pasts are imperfective while, in the Germanic languages, they are aspectually neutral. The comparison between languages of the two language families will then allow me to be more precise about the contribution of aspect to modality. Then, as the outline of the literature indicates, there are roughly two theoretical options as regards the semantics of past tenses: it can be defined epistemically as encoding the exclusion of the eventuality from the speaker's reality or it can be described by means of deictic and aspectual features. In the paper, I will defend the second view, for two reasons: (i) as will be illustrated in section 2.1, the modal interpretations of past tense may be contextually cancelled, which is hardly compatible with a core meaning conceived of as modal in nature; (ii) the epistemic conception of past tenses offers no explanation for 'fake aspect', i.e. the aspectual bleaching of imperfects that may be observed in modal uses with no past-reference, i.e., with 'fake tense'.

The objective of the paper is thus to get a more unified account of the semantic and pragmatic functioning of past tenses when they convey modality. In my view, this amounts to providing adequate answers to the following crucial questions, which are often treated as peripheral issues, if not ignored:

(i) Which modal categories may be expressed by past tenses? Are they correlated with specific linguistic parameters? Is it possible to draw a classification based on such parameters?

(ii) What is the respective contribution of tense and aspect to modality in each type of use?

(iii) Do neutral pasts behave the same way as imperfects with respect to their modal interpretations?

(iv) What are the pragmatic processes that give rise to modal interpretations?

(v) Why are tense and aspect fake in some modal contexts?

The paper is organised as follows. In Section 2, I introduce some background assumptions about the semantics of past tenses and their interpretation(s) in relation to specific readings of the reference point. Section 3 justifies the methodology, notably the choice of the 6 languages under investigation, and presents the linguistic parameters relevant to the analysis. Section 4 offers a detailed analysis and classification of the modal uses of past tenses observed in the data. Finally section 5 expands on the idea that the interpretations of past tenses in modal contexts correspond to pragmatic inferences (notably scalar implicatures) and reflect a more or less advanced stage of semantic changes.

\section{Background assumptions}

In the section, I expose a formal model that relies on a number of facts either observed in the literature or in my own corpus (see section 3.1). This model aims at providing the formal apparatus necessary to give an accurate description of the modal interpretations of past in section 4 , which is then the basis for the explanatory account and diachronic predictions presented in section 5.

The section includes six subsections. In the first two subsections, I argue for an aspecto-temporal conception of the schematic meaning of past tenses. In the following four subsections, I suggest that the different interpretations of past tenses are related to specific instantiations of the reference point $\mathrm{R}$ : subsection 2.3 introduces the different possible instantiations of $\mathrm{R}$, subsection 2.4 deals with the default interpretation in prototypical contexts, and subsections 2.5 and 2.6 finally present the cases of marked interpretations in reported speech and in the preludic use. 


\subsection{Past morphology means past}

Studies arguing for an epistemic conception of past tenses generally rely on the observation that past tenses may be modally interpreted as previously exemplified in (1)-(6). However, these studies do not usually take into account the facts that these modal interpretations may be contextually cancelled, as has been amply shown for instance for conditionals (see Andersen 1951 or Stalnaker 1975). This point is illustrated by the following examples, in which the modal interpretations conveyed by the past tense (uncertainty in (9), (10) and (11), attenuation in (12) and counterfactuality in (13)) are cancelled by the following context in capital letters:

(9) Eng If the patient had the measles, he would have exactly the symptoms he has now. WE CONCLUDE, THEREFORE, THAT THE PATIENT HAS THE MEASLES. (Iatridou 2000)

(10) Eng He talks about this topic as if he was an expert, and, INDEED, HE IS AN EXPERT.

(11) Eng

What if you were wrong? BECAUSE I DO THINK YOU'RE WRONG.

(12) Dut

$\begin{array}{llllllll}\text { Ik wilde } & \text { graag } & \text { een } & \text { kopje } & \text { koffie, } & \text { MAAR } & \text { NU } & \text { NIETMEER. } \\ \text { I } & \text { will-PST willingly } & \text { a } & \text { cup } & \text { coffee } & \text { but } & \text { now } & \text { not more } \\ \text { 'I wanted a cup of coffee, NOW NOT ANYMORE.' } & & & \end{array}$

(13) Fre

\begin{tabular}{|c|c|c|c|c|}
\hline Paul se noyait & lorsqu & 'un & sauveteur & a plongé \\
\hline FV & when & $\mathrm{a}$ & rescuer & plunge-PRF.PRS to \\
\hline sauver. & MAIS & $\begin{array}{l}\text { PAUL } \\
\text { Paul }\end{array}$ & $\begin{array}{l}\text { S'EST NOYE } \\
\text { drown-PRF PRS }\end{array}$ & QUAND MEME. \\
\hline
\end{tabular}

'Paul was drowning when a rescuer plunged to save him. BUT PAUL HAS DROWNED ALL THE SAME.'

In (9)-(11), the improbable characterisation of the eventuality conveyed by the preterit in the first sentence ('If the patient had the measles', 'He talks about this topic as if he was an expert' and 'What if you were wrong?') is overridden by the following context ('he would have exactly the symptoms he has now', 'indeed, he is an expert' and 'because I do think you're wrong'). In (12), the sense of attenuation yielded by the preterit wilde ('wanted') is cancelled by the phrase nu niet meer ("now not anymore'). Finally, in (13), the counterfactual reading of se noyer ('drown') conveyed by the imperfect is eventually replaced by a factual reading of the eventuality due to the final sentence in the present perfect Paul s'est noyé quand même ('Paul has drowned all the same').

The preceding examples suggest that the modal effects attached to past tenses are not contextual elaborations of a modal core meaning but rather correspond to implicatures that may be cancelled. Indeed, if the produced modal meanings were specific instantiations of a modal schema, their cancellation by the context should either yield the default reading, i.e., the past interpretation, or entail an underspecified reading whereby the nature of the shift from the speaker's immediate reality (to the past or to another space different from the actual one) would remain undetermined. However, this is not exactly what happens in the quoted examples. In (12) and (13), the revised interpretation produced by the cancellation of the modal implicature is the default one, as is predicted by the epistemic theory: the eventuality is grounded in the non-immediate reality of the speaker, i.e. in the past. However, in (9)-(11) and (13), the viewpoint is neither past nor underspecified, contrary to what is predicted by the aforementioned theory, but turns out to be actual: it corresponds to the actual viewpoint of the speaker, who considers the eventuality to be valid. The latter fact does not seem compatible with the idea that past tenses encode a virtual meaning. 
Furthermore, it proves to be very difficult (if not impossible) to cancel the past interpretations expressed by past tenses. And when a non-past interpretation is possible, the validity of the eventuality is in fact extended beyond the past domain. As a result, the eventuality may be interpreted to hold both in the past and in the present (14) or to have a generic validity (15):

The patient was sick, but, in fact, he still is.

John was sick, but, in fact, he is always sick.

These facts hint at the hypothesis that past-time reference is not an implicature, but rather forms a part of the encoded meaning.

In the light of these data, the present paper advocates a deictic conception of past tenses, which appears more consistent with the possibility to cancel the modal interpretations (and the impossibility to cancel the past interpretation).

\subsection{The schematic meaning of past tenses}

In the paper, I assume that past tenses carry a schematic meaning which consists of an underspecified semantic content (see Langacker 1987). Following Langacker (1987:132), the relation between the schematic meaning of a form and its interpretations in utterances is a hyperonym-hyponym relation: its schematic meaning is a superordinate abstraction, and the different interpretations met in texts are specific subordinate elaborations of the abstract schema. However, every interpretation of a linguistic unit is not necessarily a specific instance of a schematic meaning: in particular contexts, certain interpretations may also correspond to extensions from the semantic schema (cf. Langacker 1987:6970). Later in the paper (in section 5), I develop the idea that the non-past interpretations of past tenses are pragmatic extensions of the schematic meaning.

Following the conclusions of the preceding section, I argue that the schematic meaning of past tenses can be characterised by means of deictic and aspectual features. In the wake of proposals made by authors like Klein (1994) and Gosselin (1996) and adopting a Reichenbachian terminology (see Reichenbach 1947), I take past tenses to encode a deictic meaning by expressing the precedence of a reference time or reference interval $R$ in relation to the time of speech $S$. I also accept that past tenses may convey an aspectual meaning by describing a particular relation between $\mathrm{R}$ and the time of the eventuality. In the case of imperfective tenses, $\mathrm{R}$ is included within $\mathrm{E}$ : the eventuality is consequently viewed from the inside and its boundaries are excluded from the construal, i.e., they are not asserted by the tense morpheme but may be presupposed by it (when the denoted eventuality is bounded in time). In addition, past tenses may also denote no particular relation between $\mathrm{R}$ and $\mathrm{E}$. In that case, the interpretation may be either imperfective or perfective depending on the context. I will talk about 'neutral aspect' to refer to this indeterminate aspectual feature and will call the past tenses marking neutral aspect 'preterits'. (16) and (17) summarise the schematic meaning of imperfects and preterits I have just delineated:

(16) imperfects:

$\begin{array}{ll}{[\mathrm{R}<\mathrm{S}]} & \text { [past time reference] }^{6} \\ {[\mathrm{R} \subset \mathrm{E}]} & \quad \text { imperfective aspect] } \\ \text { preterits: } & \\ {[\mathrm{R}<\mathrm{S}]} & \quad \text { [past time reference] } \\ {[\mathrm{R} 0 \mathrm{E}]} & \quad \text { [neutral aspect] }\end{array}$




\subsection{Functions of the reference point}

In the preceding section, I adopted the view that past tenses do not directly describe a relationship between the denoted eventuality and the time of speech, but that this relation is always mediated by a reference point $\mathrm{R}$ that is involved in both their deictic and aspectual components. At the level of the schematic meaning, this reference point is an underspecified point which corresponds to the abstraction of more concrete and specific meanings met in texts. For instance, in the prototypical use of past tenses, R specifically refers to:

(i) a past topic time or Tt (see also Klein 1994), i.e., the past time span about which a particular utterance makes an assertion (or asks a question) ; e.g. in 'Yesterday, the weather was nice', R specifically corresponds to the time span which corresponds to 'yesterday';

(ii) the aspectual vantage point or Ap from which the internal time of the eventuality is considered; the eventuality may thus be viewed imperfectively or perfectively depending on whether the time of the eventuality encompasses Ap or coincides with it; in the case of 'Yesterday, the weather was nice', the time of the eventuality encompasses Ap, which is located between its endpoints, the eventuality is therefore viewed imperfectively, i.e., from an internal perspective.

Moreover, in certain contexts, $\mathrm{R}$ may additionally instantiate:

(iii) an evaluation point (or Ep) from which the epistemic validity (V) of the uttered proposition is considered.

The next subsection elaborates the theoretical justifications for the third instantiation of R (as Ep) and offers a characterisation of it for the case of the default interpretation of past tenses.

\section{4. $R$ as an evaluation point within the default interpretation}

The proposed analysis relies on the observation that a declarative indicative utterance generally involves the speaker committing herself to the validity of the proposition, thus implying that 'it is true that [p]'. Commitment to p's validity is not part of the encoded meaning of the indicative $\operatorname{mood}^{7}$, but can be seen as a generalised conversational implicature that derives from Grice's maxim of quality 'Be truthful' (see Gosselin 2010:26): it follows from this maxim that the speaker only says what she believes to be true, hence assuming that 'it is true that [p]'. As an implicature, commitment to p's validity may not arise or can be cancelled in specific contexts: for instance, it does not arise with linguistic expressions that "disassert" the reality of the eventuality or denote its uncertainty (e.g. Suppose that we are wrong; or Mary didn't go to the party. Maybe she was sick); the implicature that $\mathrm{p}$ is valid may also be cancelled if the speaker admits that she is not actually telling the truth (e.g. Yesterday, I won at the lottery. No, I'm joking).

The speaker's commitment to p's validity may be seen as a meta-predicate ${ }^{8}$ that scopes over the predicate expressed in proposition $\mathrm{p}$ by assigning it the property of being true (according to the speaker's epistemic judgment). This meta-predicate can be formulated as it be true that [p]. As a predicate, it be true that [p] refers to an eventuality (one could say a 'meta-eventuality') which possesses aspectual and temporal properties, just like 'normal' eventualities. I henceforth refer to the eventuality denoted by the meta-predicate it be true that [p] as $\mathbf{V}$ (for 'validity'). V can be regarded as a stative eventuality as it involves no change over time and possesses no intrinsic endpoint. In addition, $\mathrm{V}$ receives a particular deictic and aspectual characterisation, i.e., it is located on the timeline and viewed from a certain aspectual perspective. This characterisation relies on the interpretation of an evaluation point Ep from which V is considered. By default, $\mathrm{V}$ is given a present and imperfective characterisation or, in a nutshell, the proposition is considered to be valid at the time of speech. So, for an utterance like 'Max ran fast', one gets the following characterisation of $\mathrm{V}$ ('it is true that [Max $\operatorname{run}_{\text {PAST }}$ fast]'): 
Informally, this means that the speaker believes in the present (default interpretation of $\mathrm{V}$ ) that Max did run. The corresponding interpretations of $\mathrm{V}$ (it be true that $\mathrm{p}$ ) and $\mathrm{E}$ (the event denoted in $\mathrm{p}$ ) are diagrammed in figure $1 .^{10}$

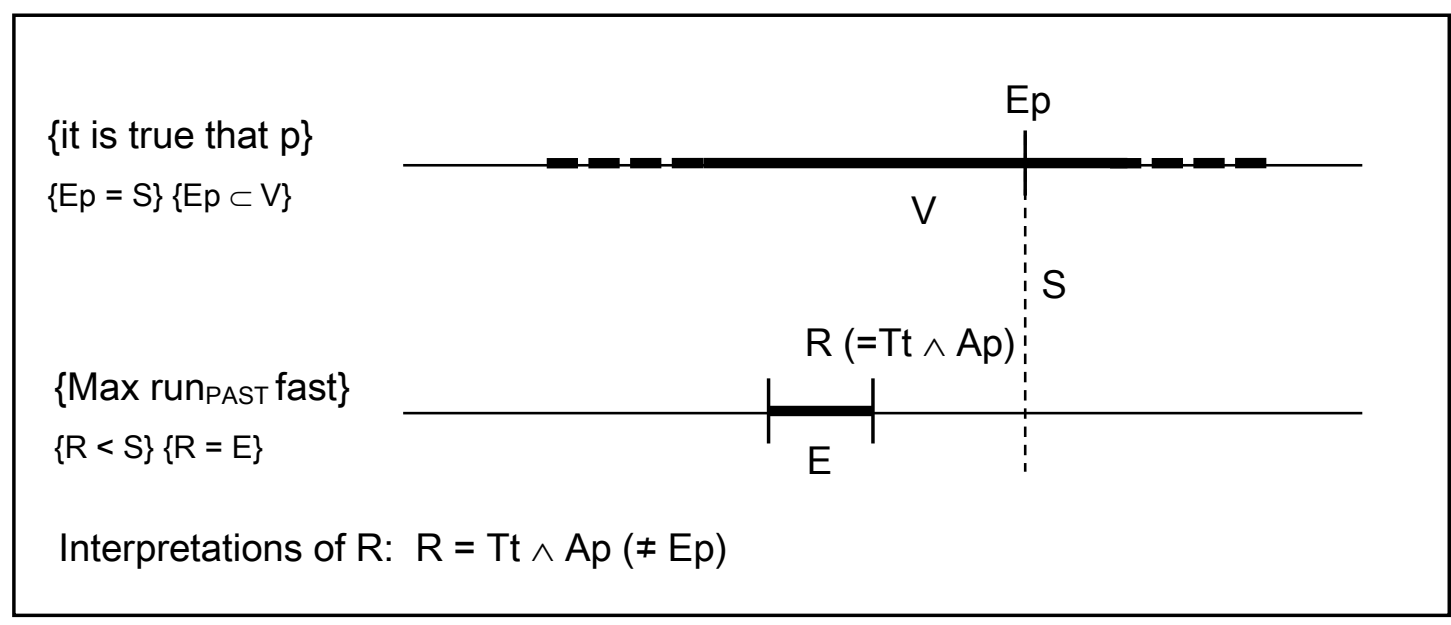

Figure 1. Aspectual and temporal interpretations of $\mathrm{V}$ (it be true that $[\mathrm{p}]$ ) and $\mathrm{E}$ (Max run fast) in the utterance 'Max ran fast'.

\subsection{Marked interpretations in past reported speech}

One may notice that the position of Ep may be modified under the influence of certain linguistic parameters. This is what happens in contexts of past reported speech ${ }^{11}$, where the past tense scopes over $\mathrm{V}$, i.e., the proposition is not taken to be valid at the time of speech but at the time of the reported utterance act. Two cases must then be distinguished depending on the aspectual properties of the predicates: past reported speech with atelic predicates and past reported speech with telic predicates.

a. Past reported speech with atelic predicates. In such contexts, Ep (and thus V) are anchored into the past and this holds for the denoted eventuality as well. In this configuration, the past tense has a double scope, which is reflected in the interpretation of the type 'it was true that $\left[\mathrm{p}_{\mathrm{PAST}}\right]$ ' where both the eventuality and its epistemic validity are past. Let us glance at example (19):

\section{Mary said that John was sick.}

Here the validity of the embedded proposition [John be PAST $_{\text {sick] }}$ is assumed to be true by the utterer Mary, who is located in the past; by contrast, the speaker who reports the past utterance does not commit herself to the validity of $\mathrm{p}$. As a consequence, the past tense 'was' has a double scope in this type of context:

(i) the past tense scopes over the proposition and therefore gives a deictic and aspectual characterisation of the described eventuality: John's being sick is viewed from a past and imperfective vantage point Ap (that of Mary); 
(ii) the past tense also scopes over $\mathrm{V}$, the validity of the proposition, and offers a past and imperfective viewpoint on it ('it was true that [John be $\mathrm{PAST}_{\mathrm{P}}$ sick]'). Consequently, the $\mathrm{R}$ denoted by the past tense takes the additional function of evaluation point $\mathbf{E p}$ from which p's validity is considered. V is thus given the following deictic and aspectual characterisation:

(20) Past and imperfective interpretation of V (in past reported speech with atelic predicates)

$$
\begin{array}{ll}
\{\mathrm{Ep}<\mathrm{S}\} & \text { \{past time reference } \\
\{\mathrm{Ep} \subset \mathrm{V}\} & \{\text { imperfective viewpoint }
\end{array}
$$

Note that the topic time which $\mathrm{R}$ refers to corresponds to the past speech time (S'), i.e., the time location of the reported utterance. In sum, $\mathrm{R}$ takes the role of $\mathrm{Tt}\left(=\mathrm{S}^{\prime}\right), \mathrm{Ap}$ and Ep. The aspectual and temporal interpretations involved by was sick in (19) are diagrammed in figure 2.

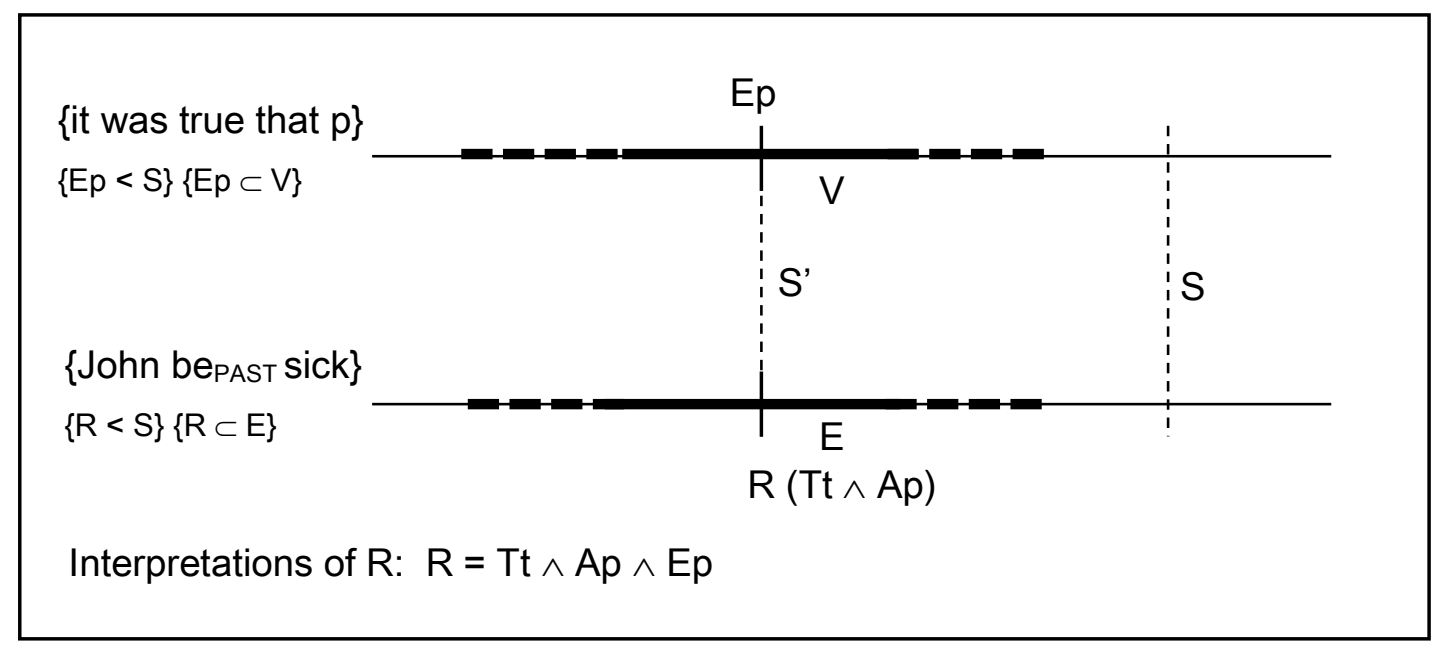

Figure 2. Aspectual and temporal interpretations of $\mathrm{V}$ (it be true that $[\mathrm{p}]$ ) and $\mathrm{E}$ (John be sick) in the utterance 'Marie said that John was sick'.

b. Past reported speech with telic predicates. When the predicate is telic, the interpretation noticeably differs: contrary to $\mathrm{Ep}$ and $\mathrm{V}$, the denoted eventuality is not grounded into the past. In this configuration, the past tense has an external scope that is reflected in the interpretation of the type 'it was true that [p]' with only the epistemic validity of the eventuality located in the past (but not the eventuality itself). Let us consider examples (21): ${ }^{12}$
a. Fre Marie a
dit que
John venait
demain.
said that
John
come-PST.IPFV tomorrow
b. Dut Marie zei
dat Jan
morgen
kwam.
Mary said that
John tomorrow
come-PST
'Mary said that John was coming tomorrow'.

In contexts like (21), telic predicates refer to eventualities that are ulterior to the reported utterance, which supposes a referential dissociation between Ep (the assertion of p's validity), which is past, and $\mathrm{E}$ (the eventuality denoted by $\mathrm{p}$ ), which is ulterior to it. As a consequence, the past tense does not bear on the eventuality anymore, but only applies to $\mathrm{V}$, the proposition's validity. In other words, past tenses have a propositional-external scope, which is manifested by two facts: 
(i) 'Fake tense' (Iatridou 2000): the past morphology does not permit us to ground the eventuality in the domain of past, but the eventuality may occur in the present or future, as show the temporal adjuncts demain and morgen ('tomorrow'); in other words, $\mathrm{R}$ does not coincide with the topic time (so that $\mathrm{R} \neq \mathrm{Tt}$ ).

(ii) 'Fake aspect' (cf. Iatridou 2000 or Squartini's 1995, 2001 'neutralised' aspect): the imperfective morphology does not impose an imperfective viewpoint on the eventuality but may also license a perfective one. Thus, in (16a), John's future coming is perceived as accomplished (and not ongoing) despite the use of the imperfect venait. Put differently, $\mathrm{R}$ does not coincide with an internal vantage point (so that $\mathrm{R} \neq \mathrm{Ap}$ ). 'Fake aspect' is confirmed by the possibility to use a delimitative adverbial (jusqu'à quatre heures and tot vier uur, 'until four o'clock') in this type of context:
a. Fre Mary a
Mary has
JUSQU'À
UNTIL
dit que
John restait
demain
said that John
stay-PST.IPFV
tomorrow
QUATRE HEURES.
FOUR HOURS
b. Dut Marie zei
dat Jan
morgen TOT
VIER UUR bleef.
Mary said
that John tomorrow
UNTIL FOUR HOUR stay-PST
'Mary said that John was staying tomorrow UNTIL FOUR O'CLOCK'.

Fake tense and fake aspect are indicative of the fact that past tenses do not scope over the proposition but over $\mathrm{V}$, the epistemic validity of $\mathrm{p}$ : the past tense then refers to a past evaluation point Ep (so that $\mathrm{R}=\mathrm{Ep}$ ) from which $\mathrm{V}$, the validity of $\mathrm{p}$, is considered ('it was true that [p]'). Here, Ep coincides with the time location of the reported utterance (S'), which amounts to saying that the past utterer believed that $\mathrm{p}$ was valid when she enunciated it. These specific aspectual and temporal interpretations are diagrammed in figure 3 , which is an analysis of example (21b).

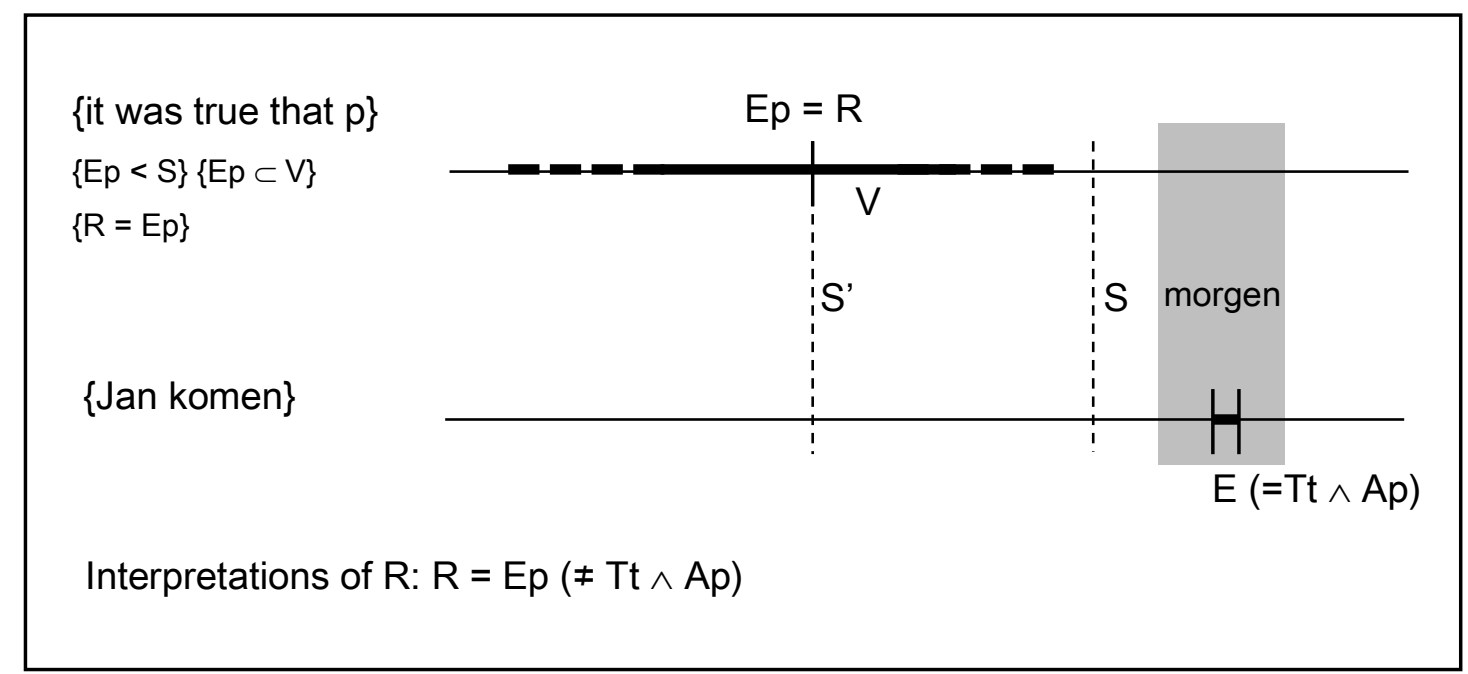

Figure 3. Aspectual and temporal interpretations of $\mathrm{V}$ (it be true that [p]) and $\mathrm{E}$ (Jan morgen komen) in the utterance 'Marie zei dat Jan morgen kwam'.

I will demonstrate in the following sections that some modal uses (the so-called epistemic, evidential and counterfactual uses) are comparable to uses in past reported speech with regard to the functions of $\mathrm{R}$ : in those contexts, the reference point $\mathrm{R}$ crucially functions as an evaluation point Ep while its 
reference to a topic time (Tt) or an aspectual vantage point (Ap) is optional. In those contexts, it is the interpretation of $\mathrm{R}$ as Ep that triggers modal inferences.

\subsection{Interpretation of $\mathbf{R}$ in the preludic use of past tenses}

In this subsection, I would like to point out that the reference point $\mathrm{R}$ may take a very specific interpretation in the speech of children playing a pretend game. This interpretation should be considered apart from the other contextual instantiations of $\mathrm{R}$ because it is, as I will suggest in the following lines, a manifestation of the immature verbal system of young children and it cannot, as such, be related to the schematic meaning proposed in section 2.2. This use, known as the 'preludic use' of past tenses, may be illustrated in the following example from Dutch:

$$
\begin{aligned}
& \text { Dut Ik was de politie en jij was de boef, oké? } \\
& \text { I be-PST the policeman and you be-PST the gangster okay } \\
& \text { 'I'm the policeman and you're the gangster, okay?' (Janssen 1994) }
\end{aligned}
$$

Some studies on the acquisition of tenses (e.g. Antinucci and Miller 1976, Fayol 1985, Ayhan AksuKoç 2006) suggest that past tenses do not have a temporal value in the verbal system of young children, but rather express, at a very early stage, a psychological distance from the speaker's here and now ${ }^{13}$. Thus, for young children who have not yet acquired temporal concepts, past tenses can refer to eventualities that belong to some past reality or imaginary worlds (as in pretend games). Following this view, I hypothesise that $\mathrm{R}$ does not function as a topic time in preludic contexts, but denotes an actuality A' other than that of the speaker's current actuality. The past tense (cf. was in (23)) then signals that the expressed eventualities are not part of what the speaker conceives of as actually real but belong to another actuality, namely the imaginary world of the game.

The different contextual instantiations of $\mathrm{R}$ that have been identified in section 2 are summarised in table 1 .

Table 1. Functions of $\mathrm{R}$ and related interpretations

\begin{tabular}{|l|c|c|l|}
\hline & Function(s) of R & Interpretation & \multicolumn{1}{|c|}{ Examples } \\
\hline Typical context & $\{\mathrm{Tt}\}$ & $\{\mathrm{Tt}<\mathrm{S}\}$ & Max ran. \\
Reported speech $(\mathbf{1})$ & $\{\mathrm{Ap}\}$ & $\{\mathrm{Ap} \subset \mathrm{E}\}$ & \\
with unbounded processes & $\{\mathrm{Ap}\}$ & $\{\mathrm{Ap} \subset \mathrm{E}\}$ & Mary said that John was sick. \\
Reported speech $(2)$ & $\{\mathrm{Ep}\}$ & $\{\mathrm{Ep}<\mathrm{S}\}\{\mathrm{Ep} \subset \mathrm{V}\}$ & \\
with bounded processes & $\{\mathrm{Ep}\}$ & $\{\mathrm{Ep}<\mathrm{S}\}\{\mathrm{Ep} \subset \mathrm{V}\}$ & Marie a dit que John venait demain. \\
Preludic use & & & \\
\hline
\end{tabular}




\section{Methodology}

\subsection{Data}

The proposed account of the modal uses of past tenses relies on data from three Romance and three Germanic languages, viz. French, Italian, Spanish, Dutch, English and German. This choice was motivated by two reasons.

First, Romance and Germanic languages possess two different aspectual systems in the domain of past:

(i) Romance languages exhibit an aspectual opposition between a perfective past and an imperfective past; only the latter is normally associated with modal meanings.

(ii) Germanic languages have one single past tense, a preterit, which is neutral as regards aspect but may nonetheless convey modal interpretations too.

The comparison of languages from these two families is meant to help elucidating the role of aspect (whether imperfective or neutral) in the interpretation of modal meanings and allow a more comprehensive account that is not restricted to either imperfects or preterits, as is generally the case in the literature.

I have further selected three languages in each language family (French, Italian and Spanish, on the one hand, and Dutch, English and German, on the other hand), which are well described so that ample data can be gathered on the topic. I have not resorted to corpora because a number of modal interpretations (e.g. the hypocoristic use (2), the 'commercial' use (3) or the preludic use found in children's speech (see section 4.5)) occur in extremely specific contexts, which are unlikely to be found in the usual corpora. However, the data collected in the literature (reference grammars, papers etc.) were supplemented by examples taken from the internet, mainly with the help of Google Books. Thanks to this method, I have gathered 385 occurrences of past tenses associated with a modal interpretation in the targeted languages. By means of these data, I have worked out a classification of the modal uses of past tenses. This classification is based on the criteria presented in the following section.

\subsection{Criteria}

a. The first criterion is the speaker's intentionality or motivation when using a past tense, i.e., her communicative purpose when choosing a specific tense (instead of another). In the case of the modal uses of past tenses, the intentionality is said to be 'modal' insofar as it is not primarily concerned with the temporal grounding of the eventuality (or the viewpoint on the eventuality) in time, but rather corresponds to a subjective or intersubjective attitude conveyed by the tense employed. Hence, the speaker's intentionality may be:

(i) epistemic: the speaker wishes to communicate the uncertainty or unreality of the eventuality;

(ii) evidential: ${ }^{14}$ the speaker wants to refer to the source or evidence for her statement;

(iii) intersubjective: the speaker intends to express a specific attitude towards the hearer, typically politeness.

The speaker's modal intentionality may be revealed by means of substitution tests. If the modal effect vanishes when a tense is replaced by another one, this means that the use of the substituted tense was serving a modal purpose. To illustrate this, let us consider the following example from German: 


$\begin{array}{lllllll}\text { Ger } & \text { Was gab } & \text { es } & \text { eigentlich } & \text { morgen } & \text { im } & \text { Theater ? } \\ \text { What gave } & \text { it } & \text { really } & \text { tomorrow } & \text { at } & \text { theater } \\ \text { - Morgen } & \text { gab } & \text { (/gibt) } & \text { es } & \text { den } & \text { Faust. } \\ \text { - Tomorrow } & \text { give-PST } & \text { (/ give-PRS) it } & \text { the } & \text { Faust. }\end{array}$

'What was to be shown at the theatre tomorrow?

- Tomorrow there was supposed to be the Faust'. (Wunderlich 1970)

Here, the preterit $g a b$ expresses evidentiality: it signals that the speaker has no direct evidence for her statement but relies on a past source. By contrast, the present tense gibt conveys no such evidential interpretation: the speaker merely asserts the validity of the eventuality, namely that Faust will be played in the future at the theater. This contrast between $g a b$ and gibt indicates that the use of preterit is motivated by the speaker's evidential intentionality.

It should be noted that the speaker's intentionality may be both temporal and modal in some contexts, that is, the past tense is used to anchor the eventuality in time as well as to express a modal attitude of the speaker. This is the case in example (25):

\begin{tabular}{|c|c|c|c|c|c|c|}
\hline (25) Fre & $\begin{array}{l}\text { Un pas } \\
\text { One step } \\
\text { (/ écrasa }\end{array}$ & $\begin{array}{l}\text { de plus } \\
\text { of more } \\
\text { / écrase) }\end{array}$ & $\begin{array}{l}\text { et } \\
\text { and }\end{array}$ & $\begin{array}{l}\text { cette } \\
\text { this }\end{array}$ & $\begin{array}{l}\text { voiture } m \text { ' } \\
\text { car me }\end{array}$ & $\begin{array}{l}\text { écrasait. } \\
\text { crush-PST.IPFV }\end{array}$ \\
\hline
\end{tabular}

'One more step and this car would have run (/ ran / is running) over me.'

(Duhamel, Chronique des Pasquier)

The imperfect écrasait features a counterfactual interpretation motivated by an epistemic intentionality whereby the speaker intends to communicate the unreality of the eventuality. This is confirmed by the substitution of écrasait ('would have run over') by the perfective past écrasa ('ran over'), which entails a factual reading. In addition, the use of the imperfect seems to serve a temporal motivation too: by using a past tense, the speaker wishes to locate the eventuality on the timeline and characterise it as past; in contrast, this past interpretation disappears with the use of a present form (cf. écrase 'is running over'). In conclusion, the speaker's intentionality when using the imperfect here can be seen as both epistemic and temporal.

b. The second criterion is the origin of modality in the modal uses, i.e., the respective contribution of the deictic and aspectual import of past tenses in the modal interpretation. Substitution tests highlight the fact that, although both tense and aspect usually contribute to the modality, aspect may also be the sole determining parameter. This is true of the conative use of imperfect, which can be observed in French:

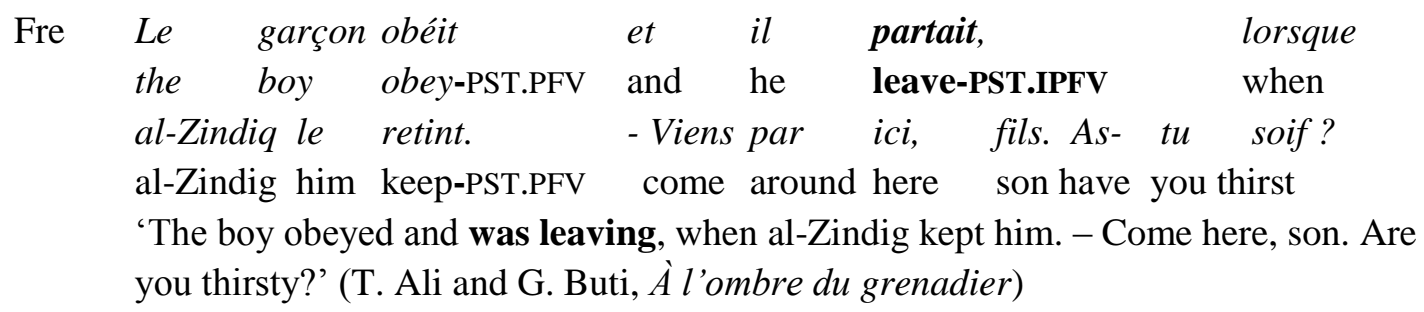

In (26), the use of the imperfect (partait) conveys a counterfactual meaning: the departure almost took place but eventually did not come true; in other words, the denoted event is excluded from the (past) reality. The use of an historical present (part, 'is leaving') in lieu of the imperfect brings about the 
same counterfactual interpretation. Given that either tenses (the imperfect and present tense) allow imperfective interpretations and the crucial semantic difference between the two morphemes is deictic in nature, one must conclude that the past component of the imperfect plays no role in the interpretation of counterfactuality, but only serves to ground the eventuality in the past. If one now replaces the imperfect by a perfective past (cf. (26')), the sentence receives a different reading: the eventuality denoted by partit ('left') is understood as completed:

Fre Le garçon obéit
the boy obey-PST.PFV and he leave-PST.PFV when
al-Zindiq le retint.
al-Zindig him keep-PST.PFV come around here son have you thirst
'The boy obeyed and left, when al-Zindig kept him. - Come here, son. Are you
thirsty?'

(26') shows that the counterfactual reading crucially depends on imperfective aspect. One can thus conclude that imperfectivity is the only ingredient in the meaning of the imperfect that contributes to the counterfactual reading in this example.

Conversely, in the following example from Spanish, both the deictic and aspectual parameters convey a modal sense:

\begin{tabular}{|c|c|c|c|}
\hline Spa & $\begin{array}{l}\text { De qué buena gana } \\
\text { For what good wish }\end{array}$ & $\begin{array}{l}\text { me } \\
\text { me }\end{array}$ & $\begin{array}{l}\text { bebía } \\
\text { drink-PST.IPFV }\end{array}$ \\
\hline & /*bebo) & un & vaso \\
\hline & / drink-PRS) & $\mathrm{a}$ & glass with that \\
\hline
\end{tabular}

In (27), the imperfect bebia expresses an epistemic meaning: the realisation of the speaker's wish is presented as uncertain. In this context, the imperfect cannot be replaced either by the past perfective bebi or by the present tense bebo without making the sentence ungrammatical. It follows that the characterisation of the eventuality as uncertain originates from both the past and imperfective features of the imperfect.

c. The third and final criterion concerns the specific instantiations of the reference point $\mathrm{R}$ according to the context of use. In section 2.3, I discriminated four different functions: $\mathrm{R}$ may refer to (i) a past topic time Tt, (ii) an aspectual vantage point Ap, (iii) an epistemic evaluation point Ep or (iv) an actuality A' other than that of the speaker. My claim is that, in the modal uses of past tenses, R does not always play the role of Tt and Ap found in the prototypical uses of past tenses (see figure 1 and table 1), but may further assume the function of Ep or A'. To substantiate this claim, take the following example from Italian:

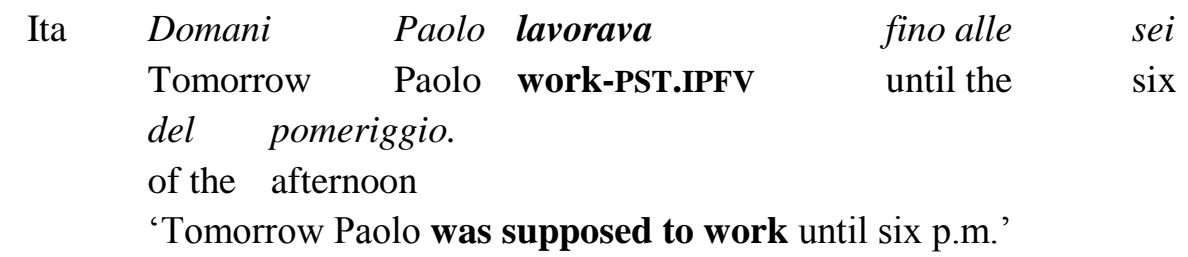


The past reference point denoted by the imperfect lavorava does not coincide with the topic time which is future in the context, as signaled by domani ('tomorrow'). Secondly, R does not serve as an aspectual vantage point Ap either. Indeed, as noted by Squartini (2001:309), the imperfect neutralises its aspectual imperfective value in this type of context and allows for a perfective reading of the eventuality (see the delimitative adverbial fino alle sei del pomeriggio 'until 6 P.M.'). In fact, in this example, $\mathrm{R}$ does not assume the typical functions of $\mathrm{Tt}$ and Ap, but only that of Ep. Indeed, lavorava conveys a sense of evidentiality by signaling that the eventuality was planned to occur in the past and the speaker has no direct knowledge about the eventuality in the present. So R refers to the past source for the statement or, put differently, to a past Ep from which the validity of the proposition is attested. The interpretation of example (29) is diagrammed in figure 4.

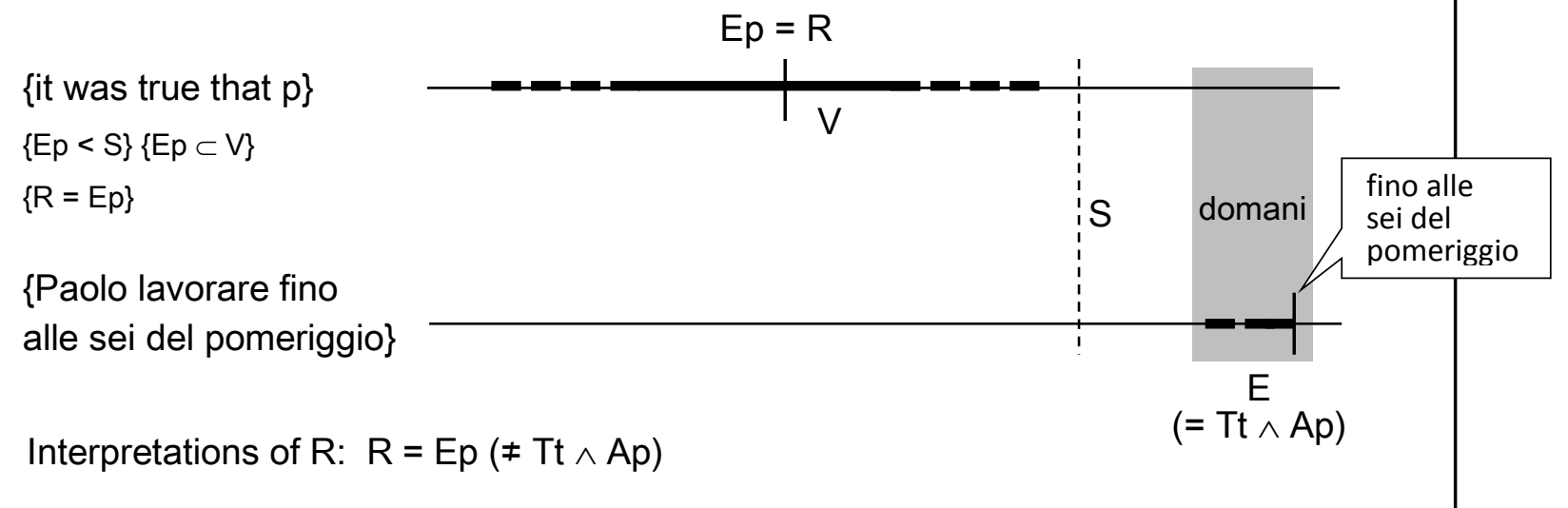

Figure 4. Aspectual and temporal interpretations of V (it be true that $[\mathrm{p}]$ ) and E (Paolo lavorare fino alle sei del pomeriggio) in the utterance 'Domani Paolo lavorava fino alle sei del pomeriggio'.

On the basis of the three criteria I have just exposed, the next section offers a classification of the modal uses of the past tenses identified in the six Romance and Germanic languages examined.

\section{Classification of the modal uses of past tenses}

The proposed classification includes five categories of modal uses: the (i) epistemic uses, (ii) evidential uses, (iii) counterfactual uses, (iv) intersubjective uses and (v) the preludic use.

\subsection{Epistemic uses}

This category covers the largest array of modal uses observed in the studied languages. It comprises contexts as various as conditionals (29), comparatives (30), optatives/desideratives (31), suppositives (32), propositives (33) and hortatives (34). As I explain later, past tenses convey in these contexts an epistemic sense which may lend itself to additional modal overtones that are not necessarily epistemic (e.g. desiderative, hortative, or propositive meanings):

$\begin{array}{lllllll}\text { Spa } & \text { Si } & \text { tuviera } & \text { dinero, me } & \text { compraba } & \text { una } & \text { moto } \\ & \text { If } & \text { have-SBJV } & \text { money, me } & \text { buy-PST.IPFV } & \text { a } & \text { motorcycle } \\ \text { 'If I had money, I would buy a motorcycle'. (Briz Gómez 2004) }\end{array}$

'If I had money, I would buy a motorcycle'. (Briz Gómez 2004) 


$\begin{array}{llll}\text { Dut Vertrok } & \text { hij } & n u & \text { maar! } \\ & \text { leave-PST } & \text { he } & \text { now but }\end{array}$

'I wish he was leaving now!' (Janssen 1994)

(32) Eng Suppose you were a rose and I was a whip-poor-will. (R. Miller)

(33) Fre Si vous retiriez votre chapeau?

If you take off-PST.IPFV your hat

'What about taking off your hat?' (A. Gide, Les faux-monnayeurs)

(34) Eng It's high time you were all in bed! (L. Caroll, Alice in Wonderland)

These contexts have the following features in common:

(i) Tense and aspect contribute both to the interpretation of modality.

(ii) The speaker wishes to specify the epistemic status of the eventuality, indicating that its realisation should be considered as uncertain. Sometimes, the final interpretation may be that the eventuality is excluded from the real world. However, in this case, it is not the past tense that is responsible for this (counterfactual) reading, but the possibility to interpret counterfactuality is due to other contextual elements (the actionality of the predicate, the presence or absence of certain temporal adjuncts, our knowledge of the world, etc.). ${ }^{15}$ For instance, stative predicates (like have in (35) given below) tend to convey a counterfactual interpretation that excludes the eventuality from the real world:

Eng If your plants had enough light, they would be doing much better. (Arregui 2007)

(iii) $\mathrm{R}$ functions as a past evaluation point Ep from which the validity of $\mathrm{p}$ is asserted.

The last point needs to be further elaborated. One may first notice that $\mathrm{R}$ does not coincide with the topic time, which is always non-past (see $n u$ 'now' in (31) and demain 'tomorrow' in (30)); in other terms, the tense is 'fake' in these contexts. Secondly, the imperfective morphology can generate perfective interpretations. This is illustrated in (29) (but see also (30) and (31)), in which the hypothetical eventuality comprar una moto ('buy a motorcycle') is seen as completed: the speaker does not imagine that she is engaged in the process of buying a motorcycle, but that she has actually been able to buy it. This observation suggests that aspect is also 'fake' in these contexts. In fact, past tenses do not bear on the eventuality described, which is why the latter receive no past and imperfective characterisation, but they only bear on $\mathrm{V}$, the epistemic validity of the proposition. In some languages (notably French, English and Dutch), V can be made explicit by means of the expression meaning 'it is true that'. Let us examine (35'), with which (35) is synonymous: better.

(35') proves that the English preterit does not scope over the eventuality denoted by the proposition (the latter is described by means of the present 'have'), but over an epistemic judgment concerning the proposition in the protasis: it be true that $[\mathrm{p}] . \mathrm{V}$ then receives a deictic and aspectual characterisation: it is viewed from an internal evaluation point Ep is located in the past, or, put simply, $p$ is held to have been valid in the past: 'it was true that [your plants have enough light]'. Example (35) illustrates the 
fact that the epistemic meaning conveyed by preterits in conditionals, and more broadly by past tenses in epistemic uses, relies on the interpretation of a past Ep from which the validity of $p$ is attested. I will spell out in section 5.2 how epistemic modality is pragmatically derived from the reference to a past Ep. The aspecto-temporal interpretations attached to the epistemic uses are illustrated in (35) figure 5, which offers an analysis of example (35).

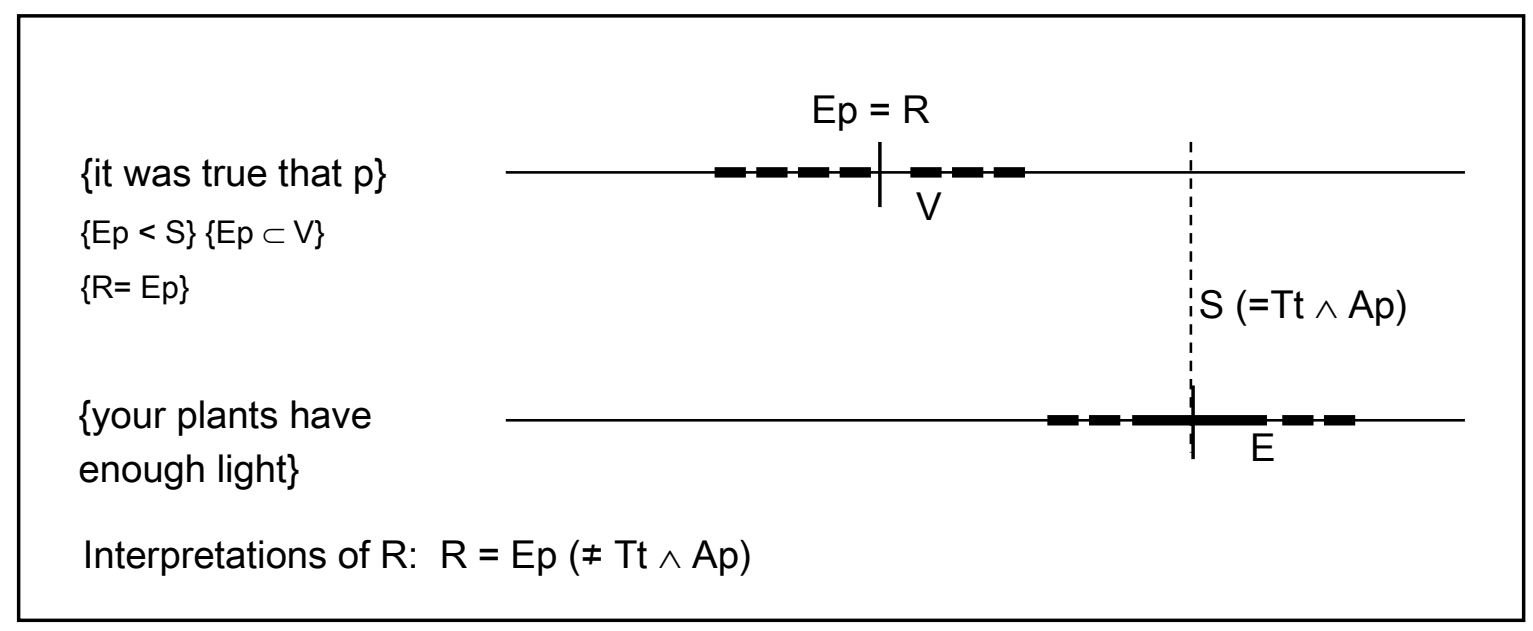

Figure 5. Aspectual and temporal interpretations of $\mathrm{V}$ (it be true that $[\mathrm{p}]$ ) and $\mathrm{E}$ (your plants have enough light) in the utterance 'If your plants had enough light, they would be doing much better'.

It should finally be remarked that epistemic modality may be accompanied by additional modal inferences that are based (at least partly) on the epistemic meaning. In suppositives (32), propositives (33) and hortatives $(34)^{16}$, the past tense also expresses a polite attitude of the speaker. Indeed, the type of utterance expressed by the speaker (a supposition, a proposition or an exhortation) calls for an appropriate response from the hearer, who is expected to consider the described eventuality (in the case of suppositives and sometimes propositives) or to contribute to its realisation (in the case of propositives and hortatives). For this reason, the speaker may weaken the potentially menacing character of her utterance by presenting the eventuality as uncertain. Following Brown and Levinson (1987), one may conclude that the use of an epistemically-interpreted past tense in suppositives, propositives and hortatives is a conventional mark of 'negative politeness' thanks to which the speaker intends to soften a potentially threatening act.

\subsection{Evidential uses}

In the studied languages, the evidential uses ${ }^{17}$ are found in two types of context in which the speaker's statement relies on a past source or evidence: echo-questions (36) and utterances describing thwarted plans (37):

$\begin{array}{lllllll}\text { Ita } & \text { Che } & \cos a & c^{\prime} & \text { era } & \text { domani } & \text { al cinema? } \\ & \text { what thing there } & \text { be-PST.IPFV tomorrow } & \text { at the cinema }\end{array}$

'What was tomorrow at the cinema?' (Bertinetto 1986) 


$\begin{array}{cccl}\text { Spa A: - ¿Qué sabes } & \text { de } & \text { Juan? } \\ \text { What know } & \text { of } & \text { Juan } \\ \text { B:- Llegaba } & \text { el } & \text { martes } \\ \text { arrive-PST.IPFV } & \text { the } & \text { Tuesday }\end{array}$

'A: What do you know about Juan? B: He was supposed to arrive on Tuesday.'

(Leonetti and Escandell-Vidal 2003)

This category of uses is similar to the epistemic uses in two respects:

(i) Tense and aspect contribute both to the interpretation of modality.

(ii) $\mathrm{R}$ exclusively functions as an evaluation point Ep from which the validity of the proposition is considered. Ep may be made explicit by means of a verbum sentiendi (36') or dicendi (37'):

che cosa HAIVISTO che $c^{\prime}$ era what thing HAVE SEEN that there be-PST.IPFV

domani al cinema? 'What DID you SEE was on tomorrow at the cinema?'

$\begin{array}{lllll}\text { Spa } & H A \quad D I C H O & \text { que llegaba } & \text { el martes. } \\ & \text { HAVE SAID } & \text { that arrive-PST.IPFV } & \text { the } & \text { Tuesday } \\ \text { 'He SAID that he was arriving on Tuesday.' } & & \end{array}$

Ep then corresponds to the time location of the past utterance act that is expressed. One may further observe that tense and aspect are 'fake' in these contexts. $\mathrm{R}$ does not coincide with the topic time that is generally anchored in the future (cf. domani 'tomorrow' in (36) and el martes 'on Tuesday' in (37)). Similarly, $\mathrm{R}$ does not take the role of internal vantage point from which the eventuality would be viewed (see the perfective interpretation of llegar 'arrive' in $(37)^{18}$ ). In sum, past tenses have a propositional-external scope and only refer to a past Ep from which the validity of $p$ is attested ('it was true that $\left.[\mathrm{p}]^{\prime}\right){ }^{19}$

(iii) Despite these similarities, evidential and epistemic uses are different with regard to the speaker's intentionality and the produced interpretation. In the case of evidential uses, the speaker signals that the only available source for her statement is past and that she is lacking direct evidence at the present time. In doing so, the speaker suggests to the hearer that some extra information is required to complete (in (36)) or confirm (in (37)) her present knowledge about the eventuality. So the use of a past tense is not primarily concerned with the epistemic status of the eventuality (as is the case in epistemic uses), but pertains to the speaker's (lack of) evidence for her statement. The contrast between the two kinds of interpretation may seem minimal since the evidential interpretation usually goes hand in hand with an epistemic meaning: when the speaker only possesses indirect evidence for her statement, the realisation of the eventuality is normally inferred to be uncertain. However, there is an important difference between both types of interpretation: while the speaker is clearly positing the existence of a past source in evidential uses, there is no overt past reference to be interpreted in the epistemic contexts (even though there exist signs of covert past reference as we saw in 4.1). This difference is crucial to distinguish both types of use, about which I will suggest in section 4 that they may illustrate two different stages of one and the same semantic evolution.

\subsection{Counterfactual uses}

A third category of modal uses is that of counterfactual uses. Interestingly, this category includes two uses that are well attested in the Romance languages, but quite rare in the Germanic ones. ${ }^{20}$ These uses are known as the de conatu use ${ }^{21}(38)$ and the use of 'thwarted imminence, 22 (39): 


$\begin{array}{llllll}\text { Spa } & \text { Salía } & \text { del } & \text { trabajo, cuando el jefe } & \text { me } & \text { llamó. } \\ & \text { leave-PST.IPFV from the } & \text { work, when the boss } & \text { me } & \text { call-PST.PFV }\end{array}$

'I was leaving work when the boss called me.'

(Ferraro and López 2002)

Fre Une seconde de plus $\quad$ [le taureau] l'
one second the bull him
'One more second and the bull would have gored him.'
(G. Flaubert, Un coeur simple)

éventrait. gore-PST.IPFV instantiation of the use of thwarted imminence (also see section 5.2.2.1):

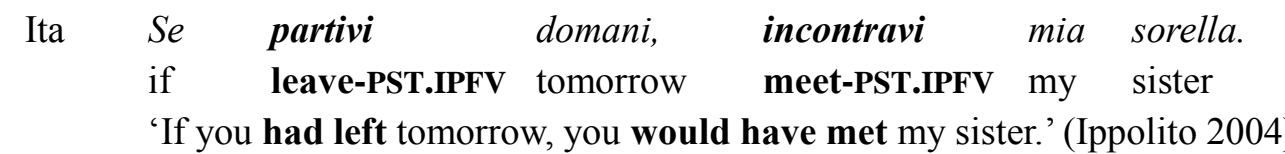

The counterfactual uses share the following properties:

(i) First, aspect contributes to modality in both counterfactual uses. In the de conatu use, the counterfactual interpretation appears as a direct exploitation of the so-called 'imperfective paradox' (cf. Dowty 1979). The 'imperfective paradox' originally refers to entailment properties of the English progressive, but the Romance imperfects show the same properties: when combined with a telic predicate, imperfects do not entail that the eventuality occurred (e.g. 'Max was running home' $\rightarrow$ 'Max ran home' $)^{23}$ and may therefore imply that the eventuality did not occur. In section 5.2.2, I will further suggest an analysis of the imperfective paradox in terms of Gricean implicatures. But for now, I only signal that the de conatu use relies on this aspectual paradox. In the de conatu use, the imperfect always bears on a telic eventuality; ${ }^{24}$ by virtue of the imperfective paradox, the imperfect cannot entail the completion of the eventuality and, as the eventuality is typically interrupted by another one in this use (e.g. cuando el jefe me llamó 'when the boss called me' in (38)), the imperfect implicates that the eventuality did not occur. This analysis explains why Germanic preterits, which are aspectually neutral, do not have this particular use: it is because they do not exhibit the imperfective paradox. When they apply to a telic predicate (e.g., Max ran home), preterits construe the eventuality as terminated and yield a factual interpretation, just like with atelic predicates. It is therefore not surprising that Germanic preterits possess no de conatu use.

Similarly to the de conatu use, the use of thwarted imminence crucially relies on imperfectivity. Thus the substitution of the imperfect by a perfective past causes a factual reading (instead of a counterfactual one):

Fre Une seconde de plus $\quad$ [le taureau] l'
one second éventra.
'One more second and the bull gored him.'

The influence of imperfective aspect is confirmed by the fact that, in Germanic languages, the counterfactual use of the preterit is only attested with atelic eventualities (mostly stative eventualities), as exemplified in (41):

(41) There was plenty of rumors about Angel floating around school, and if only half of them were true I was dead meat. (M. Roeder, Outfield menace) 
As far as past time reference is concerned, it differently contributes to the final interpretation in the two counterfactual uses. It conveys no modal meaning in the de conatu use, as is shown by the possibility to replace the imperfect by a historical present (e.g. salgo 'leave' in (38)) without changing the counterfactual interpretation. The role of the past component is thus solely to anchor the (nonrealised) eventuality in the past domain. In contrast, in the use of thwarted imminence, the past component may or may not bring about modality, depending on the interpretation of $\mathrm{R}$ (as $\mathrm{Tt}$, Ap and/or Ep) that is favoured by the context of use (see infra point (iii)).

(ii)The de conatu use and that of thwarted imminence share the epistemic intentionality: by using an imperfect, the speaker indicates the non-realisation of the eventuality described. This epistemic interpretation may seem close to that of 'uncertain realisation' found in epistemic and evidential uses. Yet they crucially differ: in the latter contexts, the speaker does not altogether refute the validity of $\mathrm{p}$ at the time of speech, but only refuses to vouch for it; the eventuality is therefore perceived as uncertain even though it still has a chance to be realised. In contrast, in counterfactual uses, the speaker fully denies the validity of $\mathrm{p}$ in the present and expresses that the eventuality can never come true, hence the sense of \{non-realisation attached to this use. In section 5, I will expand on the pragmatic origin of this difference. Another difference is the temporal grounding of the eventuality: while the eventuality is generally non-past in epistemic and evidential uses, it is located in the past in most counterfactual contexts, although it may also be possible to refer to a future eventuality within the use of thwarted imminence (see (40)).

(iii) As for the functions of $\mathrm{R}$ in the counterfactual uses, the picture markedly differs between the de conatu use and the use of thwarted imminence. On the one hand, the instantiations of $\mathrm{R}$ in the de conatu use are analogous to those found in the typical (referential) use of past tenses: $\mathrm{R}$ assumes the functions of topic time $\mathrm{Tt}$ and aspectual vantage point $\mathrm{Ap}$, thus allowing for a past and imperfective interpretation of the eventuality; $\mathrm{R}$ additionally refers to a past Ep from which the eventuality's completion is assessed to be still possible. On the other hand, in the use of thwarted imminence, the instantiations of $\mathrm{R}$ exhibit significant variation depending on the linguistic environment. In contexts like (39) and (41), $\mathrm{R}$ clearly corresponds to a past $\mathrm{Tt}$ (the utterance is about a past eventuality) and also seemingly to an Ap (the eventuality is viewed from an internal perspective). However, in futurate contexts like (40), imperfects clearly have an external-proposition scope: the future reference denoted by domani 'tomorrow' shows that the past morphology is 'fake'; and so is aspect, as is signaled by the perfective interpretation of partivi and incontravi (both eventualities are considered as completed, albeit in a counterfactual world). These examples illustrate that the interpretation of R as Tt and Ap may vary in the use of thwarted imminence. As for the interpretation of $\mathrm{R}$ as Ep, I postpone the analysis to section 5 (cf. subsections 5.2.2.1 and 5.3.2.2). For now, I remark that there is also a variation: in a clause like (41), there seems to be no reason why $R$ should coincide with a past Ep: in contrast, when both tense and aspect are fake (cf. (40)), R exclusively instantiates a past Ep from which the validity of the proposition $(\mathrm{V})$ is attested: the belief that $\mathrm{p}$ is true is then viewed to hold in the past ('it was true that [p]').

The aspecto-temporal interpretations of past tenses in their counterfactual uses are illustrated in figure 6 , which offers an analysis of example (40). 


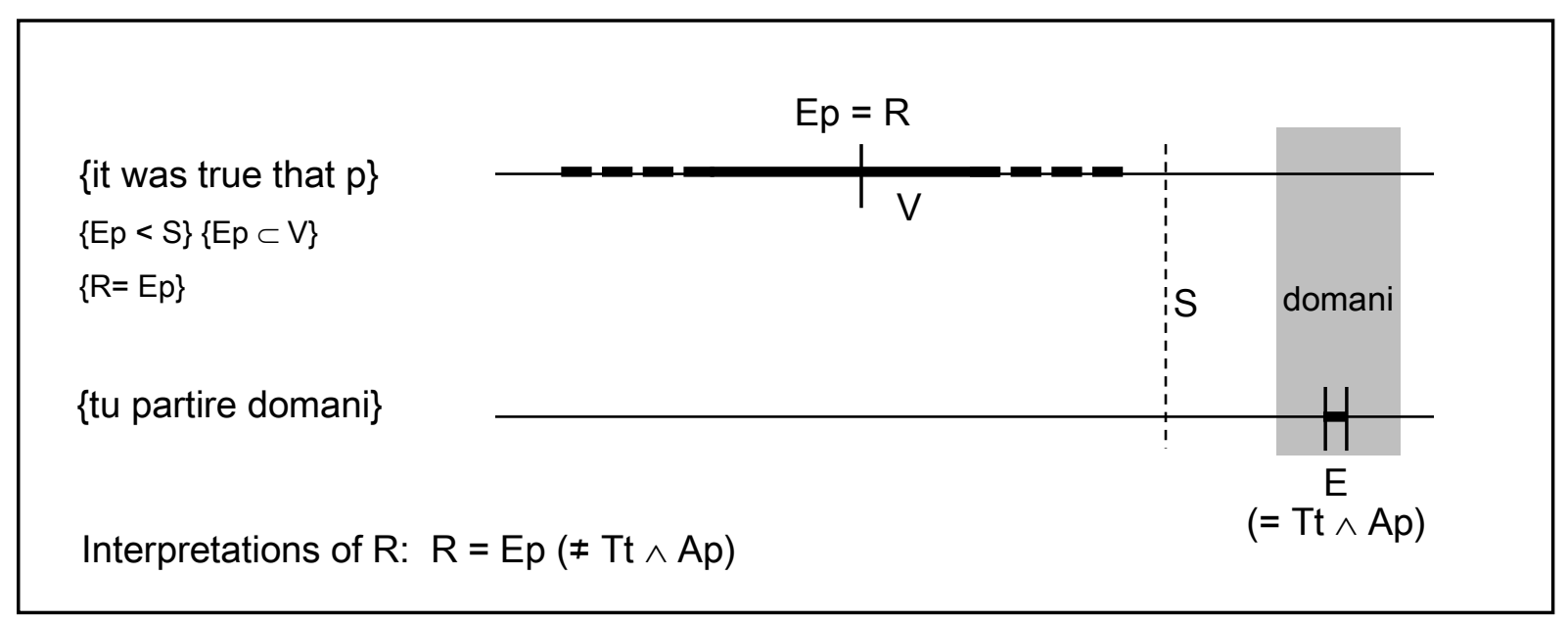

Figure 6. Aspectual and temporal interpretations of $\mathrm{V}$ (it be true that $[\mathrm{p}]$ ) and $\mathrm{E}$ (tu partire domani) in the utterance 'Se partivi domani, incontravi mia sorella.'

\subsection{Intersubjective uses}

In the studied languages, past tenses may also signal a particular attitude of the speaker vis-à-vis the hearer. Such interpersonal attitude is expressed in the use of mitigation (42), the commercial use (43) and the hypocoristic use (44):

\begin{tabular}{|c|c|c|c|c|c|}
\hline Dut & $\begin{array}{ll}\text { Ik } & \text { wilde } \\
\text { I } & \text { want-PST }\end{array}$ & $\begin{array}{l}\text { (/wil) } \\
\text { (/want-PRS) }\end{array}$ & $\begin{array}{l}\text { graag } \\
\text { with pleasure }\end{array}$ & $\begin{array}{l}e e n \\
\mathrm{a}\end{array}$ & $\begin{array}{l}\text { borrel. } \\
\text { strong drink. }\end{array}$ \\
\hline & \multicolumn{5}{|c|}{ 'I would like (/want) a strong drink'. (Janssen 1994) } \\
\hline \multirow[t]{2}{*}{ Fre } & $\begin{array}{ll}\text { Qu'est-ce qu' ell } \\
\text { what }\end{array}$ & $\begin{array}{l}\text { voulait } \\
\text { want-PST.IPFV }\end{array}$ & $\begin{array}{l}\text { la } \\
\text { the }\end{array}$ & $\begin{array}{l}\text { petite } \\
\text { little }\end{array}$ & $\begin{array}{l}\text { dame? } \\
\text { lady }\end{array}$ \\
\hline & \multicolumn{5}{|c|}{ 'What does she like, the little lady?' (Berthonneau and Kleiber 1994) } \\
\hline Ita & $\begin{array}{l}\text { Aveva } \\
\text { have-PST.IPFV }\end{array}$ & $\begin{array}{l}\text { fame la mia } \\
\text { hunger my }\end{array}$ & $\begin{array}{l}\text { bambina ? } \\
\text { little girl }\end{array}$ & & \\
\hline
\end{tabular}

The intersubjective uses share the following characteristics:

(i) Tense and aspect both contribute to the interpretation of modality.

(ii) The uses illustrated in (42) and (43) have in common that they express a polite attitude of the speaker. In the use of mitigation, politeness can be said to be 'negative' (Brown and Levinson 1987), for the past tense serves to mitigate the illocutionary force of the speaker's speech act and minimize the potentially threatening character of the utterance in the present (see the contrast between wilde and wil in (42)). In the case of the commercial use (43), politeness is rather 'positive' in that the past tense enables the speaker - most often a shopkeeper - to be thoughtful and flatter the face of the hearer most often a customer - by anticipating her desire. In the third type of use, the hypocoristic use (44), the expressed attitude is not so much one of politeness but one of caressing empathy towards the hearer, who is usually a young child or an animal. Using a past tense, the speaker signals that she is echoing what she has interpreted to be the hearer's thoughts, as if she was reporting unexpressed (past) utterances of the latter. In doing so, the speaker shows understanding and affection vis-à-vis the young child or animal. 
(iii) R functions as Ap (and possibly as Ep), but not as Tt. Indeed, Tt and the time of speech always concur in these uses, since the speaker is talking about eventualities that are the case in the present (see the quoted examples); $\mathrm{R}$ cannot therefore coincide with the present topic time implied by the utterance. Besides, $\mathrm{R}$ permits one to view the described eventuality from a past internal vantage point, thus playing the role of $\mathrm{Ap}$; the provided unbounded construal then allows one to infer that the eventuality (a past desire in (42)-(43) or a physiological state in (44)) still holds in the present. Finally, $\mathrm{R}$ is instantiated as Ep in hypocoristic utterances (see (44)), where the speaker is reporting what she has interpreted to be the thoughts of the hearer. Thus, the validity of $p$ is considered from a past evaluation point Ep, which corresponds to the presupposed past thoughts of the hearer. The aspectotemporal interpretations of past tenses in their intersubjective uses are illustrated in figure 7, which analyses example (42).

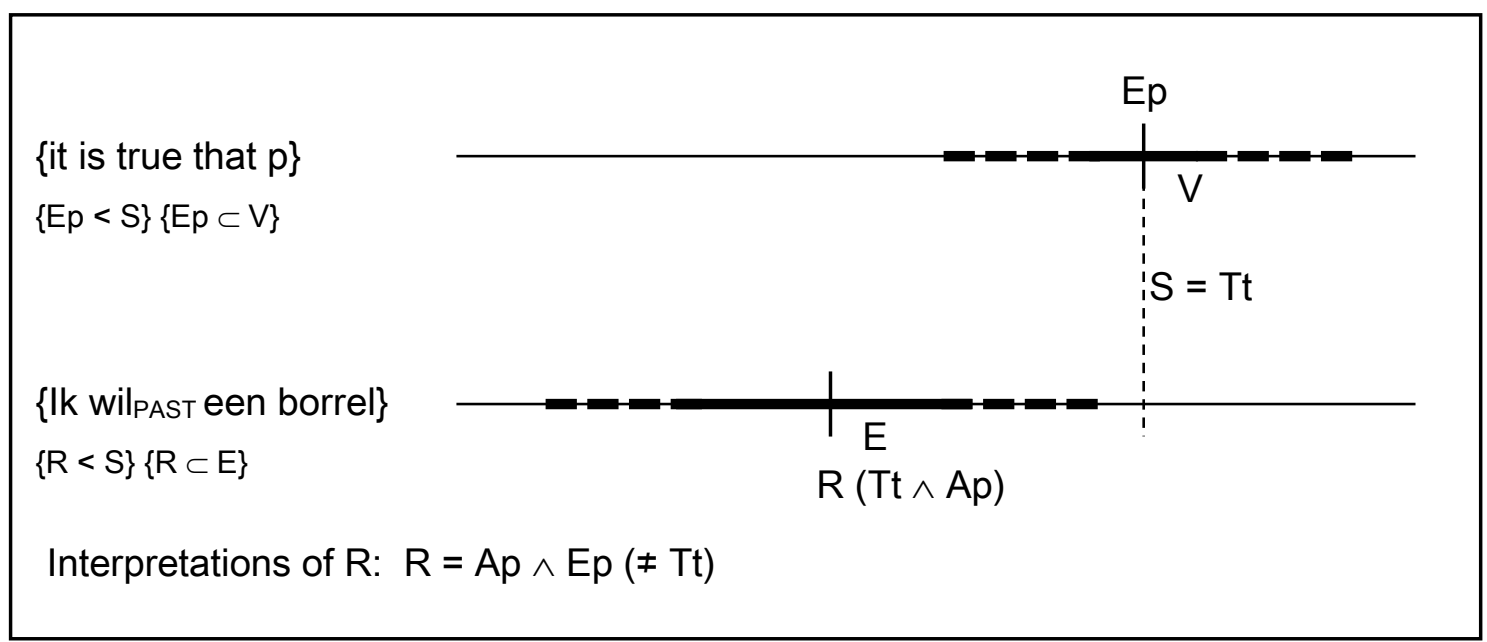

Figure 7. Aspectual and temporal interpretations of $\mathrm{V}$ (it be true that $[\mathrm{p}]$ ) and $\mathrm{E}$ (ik wil een borrel) in the utterance 'Ik wilde graag een borrel'.

\subsection{Preludic use}

The last category of use can be observed in the speech of young children playing pretend game. ${ }^{25}$ It is illustrated in (45):

$$
\begin{array}{llllllll}
\text { Fre } \quad J^{\prime} \text { étais } & \text { le } & \text { malade, et } & \text { tu } & \text { appelais } & \text { le } & \text { docteur. } \\
& \text { I be-PST.IPFV the } & \text { sick and you call-PST.IPFV } & \text { the doctor }
\end{array}
$$

'I'll be the one who's sick and you'll call the doctor' (Fleischman 1989)

This type of use can be characterised as follows:

(i) Neither tense nor aspect contributes to the produced modality. As hypothesized in 2.1, past tenses have not already acquired a genuine temporal value in the verbal system of the young child, but rather denote an actuality A' distinct from the child's current actuality. Moreover, it is interesting to note that, although young children are normally sensitive to aspectual meanings (cf. the so-called 'Aspect first hypothesis'), past tenses used in preludic contexts do not seem to convey any aspectual sense. Indeed, preludic imperfects (as in (45)) may indifferently apply to any kind of predicate, whether telic (e.g. appeler 'call') or atelic (e.g. être le malade 'be the one who's sick'); and, when combined with a telic predicate, imperfects do not denote the incompletion of the eventuality, as is usually the case with 
such predicates. ${ }^{26}$ It follows that the origin of modality should not be sought in the temporal or aspectual import of past tenses.

(ii) The child's intentionality is to anchor the denoted eventuality in the imaginary world of the game.

(iii) $\mathrm{R}$ here refers to an actuality $\mathbf{A}^{\prime}$ distinct from the child's immediate reality (see also 2.1 ). The interpretation of past tenses in the preludic use is illustrated in figure 8, which analyses example (45).

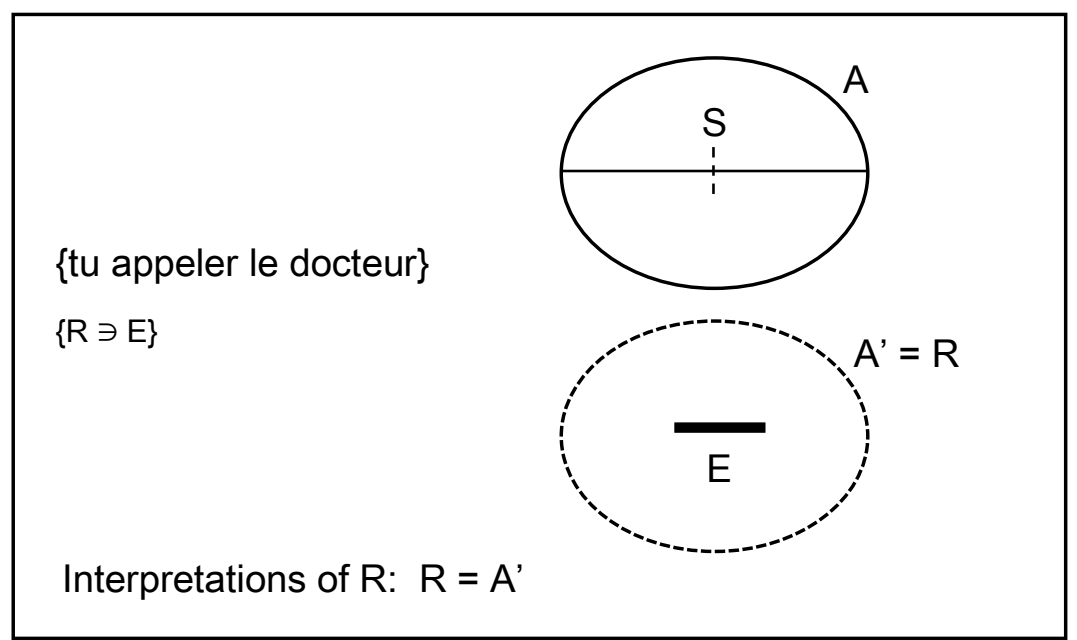

Figure 8. Interpretations of $\mathrm{E}$ (tu appeler le docteur) in the utterance ' $\mathrm{J}$ ' étais le malade, et tu appelais le docteur'.

The five categories of modal uses attested in the examined languages as well as their respective characteristics are summarised in table 2 . 
Table 2. Classification of the modal uses of past tenses attested in French, Italian, Spanish, Dutch, English and German

\begin{tabular}{|c|c|c|c|c|}
\hline $\begin{array}{l}\text { Modal uses and their } \\
\text { attestations }\end{array}$ & Contexts & Intention and related interpretation(s) & $\begin{array}{l}\text { Origin of } \\
\text { modality }\end{array}$ & Functions of $\mathbf{R}$ \\
\hline $\begin{array}{l}\text { Epistemic uses } \\
\text { Fre, Ita, Spa } \\
\text { Dut, Eng }\end{array}$ & $\begin{array}{c}\text { conditionals } \\
\text { comparatives } \\
\text { optatives/desideratives } \\
\text { propositives/suppositives } \\
\text { hortatives }\end{array}$ & $\begin{array}{ll}\text { epistemic } & \{\text { uncertain realisation } \\
\text { (intersubjective } & \text { \{negative politeness }\}\end{array}$ & $\begin{array}{l}\text { [tense] } \\
\text { [aspect] }\end{array}$ & Ep \\
\hline $\begin{array}{l}\text { Evidential uses } \\
\text { Fre, Ita, Spa } \\
\text { Dut, Eng, Ger }\end{array}$ & $\begin{array}{l}\text { echo-questions } \\
\text { thwarted plans }\end{array}$ & $\begin{array}{ll}\text { evidential } & \{\text { indirect evidence } \\
\text { epistemic } & \{\text { uncertain realisation }\end{array}$ & $\begin{array}{l}\text { [tense] } \\
\text { [aspect] }\end{array}$ & Ep \\
\hline $\begin{array}{l}\text { Counterfactual uses } \\
\text { Fre, Ita, Spa } \\
\text { Dut, Eng, Ger }\end{array}$ & $\begin{array}{l}\text { 'de conatu' } \\
\text { thwarted imminence }\end{array}$ & $\begin{array}{ll}\text { epistemic } & \{\text { non-realisation }\} \\
(\text { deictic } & \{\text { past anchoring of the situation }\})\end{array}$ & $\begin{array}{c}\text { [aspect] } \\
(\text { [tense] ) }\end{array}$ & $\begin{array}{l}\mathrm{Tt} \wedge \mathrm{Ap}(\wedge \mathrm{Ep}) \\
\text { or }(\mathrm{Tt} \text { or } \operatorname{Ap} \wedge) \mathrm{Ep}\end{array}$ \\
\hline $\begin{array}{l}\text { Intersubjective uses } \\
\text { Fre, Ita, Spa } \\
\text { Dut, Eng, Ger }\end{array}$ & $\begin{array}{l}\text { mitigation } \\
\text { commercial } \\
\text { hypocoristic }\end{array}$ & $\begin{array}{ll}\text { intersubjective } & \{\text { negative politeness } \\
& \{\text { positive politeness } \\
& \{\text { empathy } \\
\end{array}$ & $\begin{array}{l}\text { [tense] } \\
\text { [aspect] }\end{array}$ & $\operatorname{Ap}(\wedge \mathrm{Ep})$ \\
\hline $\begin{array}{l}\text { Preludic use } \\
\text { Fre, Ita, Spa } \\
\text { Dut, Eng }\end{array}$ & pretend game & $\{$ realisation in an imaginary world $\}$ & [inactuality] & $A^{\prime}$ \\
\hline
\end{tabular}




\section{The pragmatic origin of modality 5.1. Preliminary remarks}

a. As I already pointed out in 2.1, a number of studies have shown that the modal meaning encountered in conditionals correspond to implicatures that can be contextually cancelled (see Andersen 1951 or Stalnaker 1975). In the last section, I would like to generalise this claim to all the modal uses of past tenses and argue that the modal readings involved in such uses are originally pragmatic inferences (see amongst others Traugott and Heine 1991, Traugott and Dasher 2002), which have achieved different degrees of conventionalization. However, the fact that modal interpretations are still cancellable indicates that they should be viewed as generalised implicatures rather than fully conventionalised ones. ${ }^{27}$

The only exception is the interpretation of pasts in preludic contexts, which, as I suggested in sections 2.2 and 4.5, may be a consequence of children's immature temporal categories rather than the outcome of some inferential reasoning.

b. Following previous studies on modal uses of past tenses (see among others Ziegeler 2000, Ippolito 2003 and 2004, Verstraete 2006), I will show that some of the modal inferences triggered by past tenses can be viewed as scalar implicatures based on Grice's maxim of quantity ("Do not make your contribution more informative than required"). These analyses build on the idea that past tenses are less informative than alternative tense forms that could be used in same contexts, thus forming with them a scale of 'informativeness'. As a consequence, the use of a less informative past tense either leads to a strong implicature: the negation of the content conveyed by the more informative alternative (see Ziegeler 2000, Ippolito 2003 and 2004, Verstraete 2006 or section 5.2.2.1 in the present paper), or, as I will further argue, a past tense may also lead to weaker implicatures (see Ippolito 2003:173): for instance it may implicate that the speaker is not certain about the content conveyed by the more informative alternative (see 5.3.2.1). ${ }^{28}$

In the wake of the aforementioned studies, I reckon that past-time reference may contribute to modal implicatures in certain contexts or constructions; notably I suggest that past tenses form a scale of informativeness with present tenses in the sense that claiming 'it is true that p' corresponds to a stronger assertion than claiming 'it was true that p' (see 5.2.2.2 and 5.3.2.1). However, my account differs from the proposed analyses in that aspect may also trigger modal implicatures: this is the case in counterfactual uses where Romance imperfects form a scale of informativeness with perfective pasts, hence leading to the strong scalar implicature that the denoted eventuality is not realised (\{nonrealisation\}) (see 5.2.2.1).

c. Adopting a dynamic perspective, one may say that the modal uses of past tenses reflect a semantic evolution affecting these forms within particular environments (or constructions): past tenses have been increasingly used to convey modal effects (through inferential processes) so that, in certain contexts, the interpretation in terms of their source meaning is progressively backgrounded (or even overruled) while the target modal meaning is increasingly focused upon and put to the foreground. In what follows, I will attempt to give a more precise picture of this tendency on the basis of the synchronic data that I have studied. Following Heine (2002), I will distinguish two types of context bridging contexts and switch contexts - that constitute two intermediate stages of semantic change from a meaning A to a meaning B. Heine assumes that these types of contexts may be observed in synchrony, where they correspond to different uses of a same linguistic form. Following this assumption, I will now argue that the modal uses of past tenses described in section 4 either fall in the category of bridging contexts, thus signaling an early stage in the semantic move from tense and 
aspect to modality, or in the category of switch contexts, which correspond to a more advanced stage of this evolution.

\subsection{Bridging contexts}

In Heine's (2002) model for semantic change, bridging contexts represent the second phase of a fourstep scenario according to which a linguistic form acquires a new grammatical meaning. In this type of context, the source meaning carries an inference, the target meaning, which is invited by the speaker, i.e., which constitutes the very meaning the speaker wishes to convey with a particular form. In this situation, the linguistic form is semantically ambivalent in so far as it is associated with two contiguous meanings:

(i) its encoded schematic meaning (the source meaning) - and its contextual elaborations;

(ii) the extended interpretation derived by means of inferencing (the target meaning).

Among the modal uses of past tenses, the early stage of bridging contexts seems to be attained in five cases with: the de conatu use, some contexts of thwarted, and the three intersubjective uses (use of mitigation, commercial use and hypocoristic use). I will now describe in more detail the different interpretations (the source meaning and the target meaning) associated with the studied tenses in these uses.

\subsubsection{The source meaning is still available (to a certain extent)}

In the aforementioned uses, the semantic evolution has not reached the subsequent stage of switch contexts: as a result, $\mathrm{R}$ may still function as $\mathbf{T t}$ and/or Ap just as in the typical (referential) uses of past tenses. This means that the source meaning, i.e. the deictic and aspectual value encoded by the tense morphology, is still available to a certain extent, along with the inferred modality. Put differently, tense and aspect are still 'real' in bridging contexts. However, the aspecto-temporal source meaning is not equally salient in all the uses. In the de conatu use exemplified in (46) (previously quoted under (38)), the past meaning of the imperfect clearly appears in the foreground since the eventuality (salia, 'was leaving') coincides with the (past) topic time (so that $\mathrm{R}=\mathrm{Tt}$ ).

$\begin{array}{llllll}\text { Spa } & \text { Salía } & \text { del } & \text { trabajo, cuando el jefe } & \text { me } & \text { llamó. } \\ & \text { leave-PST.IPFV from the } & \text { work, when the boss } & \text { me } & \text { call-PST.PFV }\end{array}$

(Ferraro and López 2002)

Similarly, in certain configurations of the use of thwarted imminence, the source meaning also stands in the foreground of the interpretation. Here, I refer to these contexts as 'thwarted imminence $(\alpha)$ ', as opposed to contexts of 'thwarted imminence ( $\beta$ )' where the aspecto-temporal interpretation of the past tense is backgrounded (see 5.3.2.2). Example (47) offers an illustration of thwarted imminence $(\alpha)$ :

$$
\begin{aligned}
& \text { Fre Un pas de plus, elle était } \\
& \text { One step of dans la } \quad \text { more she be-PST.IPFV in the } \\
& \text { 'One more step, she would have been in the street.' (V. Hugo, Les misérables) }
\end{aligned}
$$

In this type of contexts, $\mathrm{R}$ functions as $\mathrm{Tt}$ and $\mathrm{Ap}$ and thus provides a past and imperfective characterisation of the counterfactual eventuality: the latter is anchored in the past and viewed from an internal perspective.

Similarly, the past interpretation is not obvious anymore in some intersubjective uses, notably in the use of mitigation and the commercial use, which are highly-conventionalised. I recall example (42) under (48) for the sake of illustration: 


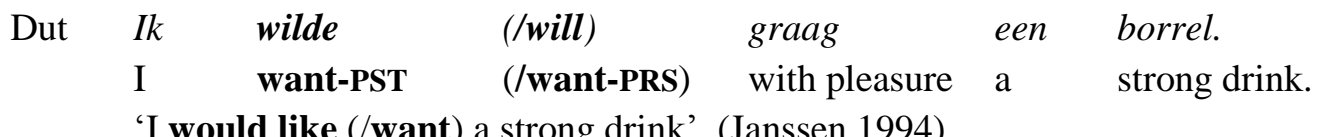

Here, the reference to a past moment lies in the background (there need not be a salient moment to be referred to in the context) and the topic time is clearly the time of speech (so that $\mathrm{R} \neq \mathrm{Tt}$ ): put simply, the speaker is making a request that holds in the present. It follows that, at the stage of the bridging contexts, the reference point $\mathrm{R}$ does not obligatorily refer to the topic time anymore. This parallels the fact that the central motivation for the use of a past tense is no longer to talk about a past eventuality, but to express an epistemic judgment (in the de conatu use and the use of thwarted imminence) or an interpersonal relation (in intersubjective uses). However, even though it is not crucial anymore to understand the utterance adequately, the source meaning of past tenses is still compatible with bridging contexts or, put differently, tense and aspect are not 'fake' in these contexts. Indeed, the eventuality can still be interpreted to hold in the past: for instance in (48), the utterance describes a desire that necessarily precedes, at least logically, the speech act in such a way that it is always possible to regard the speaker's desire as already being real in the past. Likewise, the aspectual imperfective reading of the eventuality (with $R=A p$ ) is still feasible: for instance in (42), the speaker's desire denoted by wilde is viewed as ongoing and cannot be interpreted as terminated. In brief, although it is no longer central to the understanding of the utterance, the interpretation in terms of the source meaning is still obtainable.

\subsubsection{The source meaning gives rise to a modal implicature}

At the stage of bridging contexts, the past and imperfective interpretation of the past tense may trigger three types of modal inference: \{politeness\}, \{empathy\} and \{non-realisation\}. These inferences arise because of particular contextual configurations which I now describe in some detail.

\subsubsection{The emergence of \{non-realisation\} in the de conatu use and in the use of thwarted imminence}

a. In the de conatu use (see (46)), imperfective aspect appears as the determining parameter, which explains why preterits, which are aspectually unspecified, cannot stand alone in this type of use (see 4.3). The counterfactual inference produced stems from two contextual factors: (i) the combination of an imperfect with a telic predicate (the so-called 'imperfective paradox', see section 4.3) and (ii) the interruption of the denoted eventuality by a second eventuality. Both factors converge towards an incomplete construal of the telic eventuality described with the imperfect, which leads to the counterfactual reading that the event did not occur (\{non-realisation $\})$. This counterfactual implicature is generated via Grice's 'cooperative' principle and, more precisely, the Quantity maxim (1975: 45) "Do not make your contribution more informative than is required": by using an imperfective form (e.g. salia 'was leaving' in (38)), the speaker indicates that a perfective tense would be too informative and that the eventuality's complete realisation cannot be asserted. In doing so, the speaker invites the hearer to infer that the denoted event did not in fact happen.

b. In contexts of thwarted imminence ( $\alpha$ ), the counterfactual interpretation (i.e., \{non-realisation \}) is also environmentally conditioned: it is conveyed (i) by the conditional structure linking the antecedent $\mathrm{p}$ (un pas de plus 'one more step') to its consequent q (elle était dans la rue 'she was in the street'), and (ii) by the semantic content of $p$ that describes the conditions under which the eventuality could have been realised (e.g. \{if she had walked one more step\} in $(47))^{29}-$ that is why the initial component p may sometimes correspond to a counterfactual if-clause (see examples (40) and (41) 
quoted in 4.3). ${ }^{30}$ Then, depending on aspectual parameters, the past tense may or may not contribute to the counterfactual interpretation conveyed by the construction.

\section{There was plenty of rumors about Angel floating around school, and if only half of them were} true I was dead meat. (M. Roeder, Outfield menace)

When the predicate is atelic, as in (41) repeated here as (49), the past tense does not seem to make a contribution to the counterfactual meaning, but only serves to anchor the eventuality in the past and view it from an internal perspective. Put differently, $\mathrm{R}$ functions as $\mathrm{Tt}$ and $\mathrm{Ap}$, but not as Ep. This aspectual configuration with an atelic predicate is attested in both Romance and Germanic languages (see (47) for an example from a Romance language).

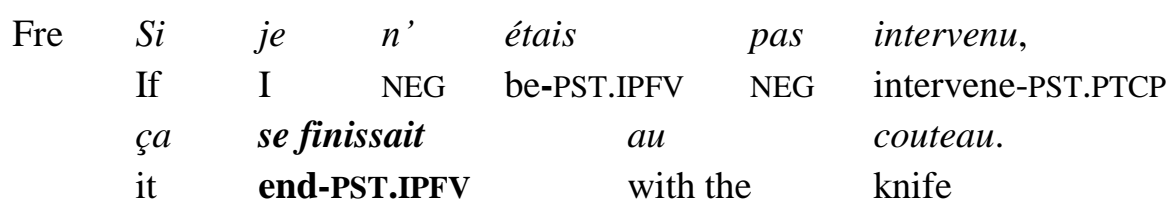

'If I had not intervened, it would have ended with knife' (Patard 2007)

With a telic predicate (as in (50)), imperfective aspect is in harmony with the linguistic environment (the structure [p, q] and the counterfactual antecedent $q$ ) in that it also entails the implicature of \{nonrealisation\}. Just as in the de conatu use, this counterfactual interpretation arises thanks to the imperfective paradox, which can be accounted for by means of a scalar implicature. On the basis of Grice's Quantity maxim (1975:45) "Do not make your contribution more informative than is required", the use of a less informative imperfects signals that a perfective tense would be too informative and that the eventuality's complete realisation cannot be asserted. The speaker thus invites the hearer to infer the \{non-realisation\} of the denoted event. Formally, the implicature of \{nonrealisation \} triggered by the imperfect is based on the interpretation of $\mathrm{R}$ as a past Ep. The inferred meaning is that the speaker believes at the time of speech that the eventuality did not occur ('it is not true that p'), but that the eventuality's factual occurrence could be conceivable at some point in the past ( $\mathrm{Ep}=\mathrm{R}$ or 'it was true that $\mathrm{p}$ '); in other words, the imperfect refers to a past moment from which the completion (and therefore the realisation) of the event is still conceived to be valid. ${ }^{31}$ In sum, $R$ functions here as $\mathrm{Tt}$ and $\mathrm{Ap}$ and, by virtue of the imperfective paradox, also as Ep.

Contexts with telic predicates are a clearly distinct case. As was just made clear, imperfective aspect implicates modality with telic predicates by virtue of the imperfective paradox, whereas it does not contribute to modality with atelic predicates (other elements in the linguistic environment are responsible for the counterfactual interpretation). In other words, in the use of thwarted imminence, imperfective aspect matters with telic predicates, but not with atelic predicates. In this respect, the use of thwarted imminence with telic predicates can be assimilated to a specific instance of the de conatu use: in both uses, the combination of an imperfective tense and a telic predicate conveys a counterfactual reading by virtue of the imperfective paradox but, in a context of thwarted imminence, counterfactuality is additionally conveyed by a counterfactual antecedent (e.g. an if-clause as in (49) and (50)).

This analysis is confirmed by a revealing contrast between the Romance and the Germanic domain: the use of telic predicates is attested in Romance languages (see (50)) but in not Germanic languages. The difference between the Romance and Germanic languages stems from the fact that Romance imperfects allow the 'imperfective paradox' with telic predicates, but not Germanic preterits ,which always entail a factual reading with bounded eventualities (e.g., Max ran home). Consequently, the use of a preterit is disfavoured in contexts of thwarted imminence since the factual realisation of the event 
is somewhat conflicting with the sense of \{non-realisation\} expressed by the linguistic environment. Accordingly, one may predict that preterits should be confined in such contexts to atelic predicates, while imperfects can also apply to (and are clearly promoted with) telic predicates. This affinity of imperfects with counterfactual contexts (by opposition to preterits) explains why the use of thwarted imminence is quite entrenched in Romance languages, whereas it remains marginal in Germanic languages.

\subsubsection{The emergence of \{politeness\} and \{empathy\} in the intersubjective uses}

In the intersubjective uses, the modal inferences derive from both the deictic and the aspectual components. One may then talk about a chain of succeeding inferences, which ultimately leads to the interpretation of an interpersonal relation with respect to the hearer:

(i) Inference 1: The imperfective and neutral aspect first enables the speaker to imply that the past eventuality still holds in the present. Indeed, as they are combined with atelic predicates in intersubjective contexts (e.g. willen 'to want' in (42)), imperfects and preterits offer an internal perspective on the eventuality, which excludes the endpoints from the construal; the hearer may consequently infer that the eventuality extends up to the present and may still be valid;

(ii) Inference 2: Past-time reference gives rise to a conversational implicature based on Grice's Quantity maxim (1975:45) "Make your contribution as informative as is required for the current purposes of the exchange". By using a past tense instead of a present tense (which should be possible by virtue of inference 1), the speaker signals that she is not willing to assert the eventuality at the time of speech even though it may still hold in the present. In doing so, the speaker invites the hearer to figure out what motivates her choice for a past tense rather than a present tense. In other words, the hearer is solicited to make the adequate inference concerning the speaker's intention, which may pertain to different interpersonal attitudes according to the context.

In contexts of mitigation, the speaker prefers to refer to past eventualities (mostly a desire or intention), because the reference to a present eventuality is seen as too direct and potentially threatening for the face of the hearer (cf. section 4.4). The use of a past tense thus invites the inference of \{negative politeness\} from the speaker. Similarly, in the commercial use, the speaker chooses to refer to the past domain so as to indicate that she has anticipated the customer's desire, hence flattering the face of the hearer (cf. section 4.4). The use of a past tense consequently invites the interpretation of \{positive politeness\}. Finally, in the hypocoristic use, the speaker utilises a past form to signal that she has well understood the hearer's thoughts (cf. section 4.4), thus implicating an attitude of \{empathy\}.

In this section, I have argued that the de conatu use, (some contexts of) the use of thwarted imminence and the intersubjective uses reflect an incipient modal move at the stage of bridging contexts (cf. Heine 2002). This move is concretely manifested by the evolution of the functions of the reference point R: its interpretation as $\mathrm{Tt}$ or Ap become less central to the reception of the utterance and, as a result, such interpretations are backgrounded or even ruled out (see the $\mathrm{Tt}$ interpretation in intersubjective contexts); meanwhile the modal implicatures triggered by virtue of the aspectual and/or deictic features of imperfects and preterits are now focused upon in the interpretation as they constitute the very message the speaker intends to convey.

The next section presents the modal contexts that represent a more advanced stage in the process of modalisation, namely the stage of switch contexts. 


\subsection{Switch contexts}

Switch contexts constitute the third stage of Heine's four-step scenario for semantic change. At this stage, the context is no longer compatible with (some aspects of) the source meaning. Three of the observed modal uses seem to correspond to this stage: the epistemic uses, the evidential uses and the use of thwarted imminence $(\beta)$.

\subsubsection{The source meaning is (partially or totally) inconsistent with the context}

In the three aforementioned uses, the interpretation in terms of the source meaning is not allowed anymore and the inferred meaning (the target meaning) is the only interpretation in the foreground. This concretely means that some aspects of the deictic and aspectual meaning of past tenses have become inconsistent with the modal interpretation produced, which is signaled by the fact that both tense and aspect are 'fake'. As demonstrated in section 4, past tenses do not then offer a deictic and aspectual characterisation of the eventuality anymore, but only scope over $\mathrm{V}$, the validity of $\mathrm{p}$ (it be true that $[\mathrm{p}]$ ). This is reflected in the interpretation of $\mathrm{R}$, which cannot function as $\mathrm{Tt}$ or Ap, but can only be interpreted as Ep, i.e. as the evaluation point from which the validity of the proposition is considered. As a result, the semantic contribution of past tenses is not to describe a past eventuality any longer, but to express an epistemic judgment about the eventuality: 'it was true that [p]'. This epistemic interpretation gives rise to further modal inferences, which constitute the very meanings that are targeted in the communication. ${ }^{32}$

\subsubsection{Tracing the origin of modal inferences}

In the switch contexts identified, the modal inferences triggered are of three sorts: $\{$ indirect evidence\}, \{uncertain realisation $\}$ or $\{$ non-realisation $\}$. I will now try to trace the contextual configurations that have permitted their emergence.

\subsubsection{1. \{Indirect evidence\} and \{uncertain realisation\}}

The origin of \{indirect evidence $\}$ in evidential uses and of \{uncertain realisation $\}$ in epistemic uses may be found in contexts of reported speech with telic predicates:

Fre Attends, $c^{\prime}$ est pas possible, elle $m^{\prime}$ a dit au téléphone,
wait it is not possible she me has said at the phone
tout à l'heure,
$\begin{aligned} & \text { a short while ago elle venait } \\ & \text { that she come-PST.IPF tomorrow only }\end{aligned}$
'Wait, this can't be possible, she said to me on the phone a short while ago that she
was coming tomorrow only...' (Barceló and Bres 2006)

As noticed in section 2.2, tense and aspect are fake in these contexts, i.e. R exclusively functions as an Ep (see supra figure 3). Thus, in (51), the imperfect venait is referring to a past Ep and V is assumed to hold in the past ('it was true that [she come tomorrow]'). I argue that this specific interpretation of $\mathbf{R}$ as past $\mathbf{E p}$ is what allows the inference of an epistemic implicature. ${ }^{33}$ Here, the implicature arises as a consequence of Grice's Quantity maxim (1975:45): "Do not make your contribution more informative than is required".

Using an imperfect or preterit, the speaker signals that a present tense would be too informative because p's validity cannot be asserted at the time of speech. In a favorable context - e.g., in (51), in the speaker is facing contradictory information from two sources, which leads the hearer to infer that $\mathrm{p}$ might not be valid anymore or, put differently, that the realisation of the eventuality is uncertain ( $\{$ uncertain realisation $\}$ ).

Such epistemic inference can also be observed in the evidential use, the only difference with reported speech being that the identity of the past source is not made explicit. However, there again, the speaker 
signals that she is not in the position to maintain 'it is true that [p]', and thus invites the speaker to infer that the source for her statement is indirect because past (\{indirect evidence $\}$ ), and so that $p$ may not be valid anymore at the time of speech ( $\{$ uncertain realisation $\}$ ) (see also section 4.2).

In the case of epistemic uses, the same modal implicature (\{uncertain realisation $\}$ ) arises but the process of modalisation seems to have gone one step further. Indeed, the interpretation of $\mathrm{R}$ as a past Ep has been backgrounded: past reference is not overt anymore in most cases, even though there are still signs of covert past reference (cf. the possibility to paraphrase by means of 'it is true that' noted in section 4.1). Observe, however, that past reference may still be in the foreground in some hybrid contexts mixing a conditional construction and reported speech, as in (52):

Eng If you earned as much as you claim, you would not go around in that old car. (Dahl 1997:108)

Here the preterit earned is thus doubly motivated: (i) it first indicates that the speaker is reporting a previous utterance (p's validity is considered from a past Ep), and (ii) it further implicates that the speaker is doubting the reality of the eventuality. It is possible that this type of hybrid context served as a 'point of penetration' (Givón 1994:318) for the extension of past tenses to epistemic contexts, but this hypothesis needs to be confirmed by diachronic data.

\subsubsection{2. \{Non-realisation\} in the use of thwarted imminence ( $\beta)$}

As was seen in section 5.2.2.1., the origin of counterfactuality in the use of thwarted imminence is a scalar implicature triggered by imperfects (by contrast with perfective pasts). It seems plausible that the contexts where this implicature may first have arisen, i.e., its 'point of penetration' (Givón 1994:318), might be contexts with telic predicates where tense and aspect are still 'real' (i.e., contexts of thwarted imminence ( $\alpha$ ), see supra (49)). In those contexts, R functions as Tt and Ap, but is also inferentially interpreted as past Ep by virtue of the 'imperfective paradox'. The imperfect then comes to refer to a past moment just before the completion (and therefore the realisation) of the eventuality stopped to be conceived as valid ('it was true that p').

The following step of contexts of thwarted imminence $(\beta)$ is attained when a distinct reading arises whereby tense and/or aspect are 'fake'. In other words, the context of use is no longer compatible with (certain aspects of) the source meaning. Utterance (53) offers an example with 'fake aspect' only and utterance (54) (previously quoted under (40)) an example with both 'fake' tense and 'fake' aspect:

(53) Fre [A father to his son who has just climbed Mount Ventoux]

$\begin{array}{lllll}\text { - Plus entraîné, } & \text { tu } & \text { le montais } \\ \text { More trained, } & \text { you } & \text { it } & \text { climb-PST.IPFV } \\ \text { en } & \text { même pas } & \text { deux } & \text { heures } \\ \text { in } & \text { same not } & \text { two hours }\end{array}$

'Better trained, you would have climbed it (Mount Ventoux) in less than two hours' (conversation < Bres 2009)

$$
\begin{aligned}
& \text { Ita Se partivi domani, incontravi mia sorella. } \\
& \text { if leave-PST.IPFV tomorrow meet-PST.IPFV my sister } \\
& \text { 'If you had left tomorrow, you would have met my sister'. (Ippolito 2004) }
\end{aligned}
$$

In (53), the eventuality described by montais ('was climbing') gets a perfective interpretation thanks to the delimitative adjunct en même pas deux heures ('in less than two hours'), however, the 
interpretation is still overtly past. As for (54), we saw in section 4.3 that the imperfects partivi and incontravi do no convey any deictic or aspectual information as regards the denoted eventualities: they are not anchored in the past (cf. domani 'tomorrow' in (52)) and they are not viewed from an internal perspective (the eventuality is seen as terminated albeit in a counterfactual world). One may analyse the extension of past tenses to such contexts with 'fake' tense and/or 'fake' aspect as the progressive weakening of the source meaning that is typical of switch contexts. Parallel to this semantic erosion, the inferred target meaning based on the interpretation of $\mathrm{R}$ as Ep is gradually reinforced as it becomes the only meaning conveyed by the past tense.

\subsection{Summary and perspectives}

In this last section, I have tried to demonstrate that epistemic uses, evidential uses and also, to a certain extent, the use of thwarted imminence could be taken to instantiate an advanced stage towards the acquisition of a modal meaning. I have suggested that they illustrate Heine's stage of switch contexts, which is characterised by the spread of modal implicatures to contexts that are incompatible to (some aspects of) the source meaning. This is evidenced by the impossibility to interpret the reference point $\mathrm{R}$ as $\mathrm{Tt}$ and $\mathrm{Ap}$, and by its sole interpretation as Ep. It is then the latter reading that triggers the inference of modality.

The analysis proposed in section 5 for the modal uses of past tenses in terms of bridging and switch contexts is summed up in table 3 .

Table 3. Modal uses of past tenses as bridging or switch contexts

\begin{tabular}{|c|c|c|c|}
\hline $\begin{array}{c}\text { Interpretation based } \\
\text { on source meaning }\end{array}$ & $\begin{array}{c}\text { Bridging contexts } \\
\{(\mathbf{T t} \wedge) \operatorname{Ap}(\wedge \mathbf{E p})\}\end{array}$ & $\begin{array}{c}\text { Switch contexts } \\
\{(\mathbf{T t} \text { or } \mathbf{A p} \wedge) \mathbf{E p}\}\end{array}$ & $\begin{array}{c}\text { Target meaning } \\
\{\text { modal inferences }\}\end{array}$ \\
\hline \multirow{3}{*}{$\mathrm{Tt} \wedge \mathrm{Ap}$} & reported speech & $\begin{array}{c}\text { evidential contexts } \\
\text { epistemic contexts } \\
\text { (including hybrid contexts } \\
\text { with reported speech) }\end{array}$ & $\begin{array}{l}(\{\text { indirect evidence }\}) \\
\{\text { uncertain realisation }\}\end{array}$ \\
\hline & $\begin{array}{l}\text { mitigation } \\
\text { commercial } \\
\text { hypocoristic }\end{array}$ & & $\begin{array}{c}\text { \{negative politeness } \\
\text { \{positive politeness } \\
\quad\{\text { empathy }\end{array}$ \\
\hline & $\begin{array}{l}\text { 'de conatu' } \\
\text { thwarted imminence }(\alpha) \\
\text { ('real' tense and aspect) }\end{array}$ & $\begin{array}{l}\text { thwarted imminence }(\beta) \\
\text { ('fake' tense and/or } \\
\text { aspect)) }\end{array}$ & $\{$ non-realisation $\}$ \\
\hline
\end{tabular}

Following Heine's scenario for semantic change (2002), the identification of bridging contexts and switch contexts allows us to make hypotheses for the developmental paths of the modal uses of past tenses. Connecting the uses with the same modal meaning and ordering them according to the conventionalisation of the targeted inference (and the backgrounding of the source meaning), one come up with three main paths of semantic change given in figure 9 (which demands diachronic studies for confirmation):

(i) the evidential and epistemic uses extended from the use in reported speech which is itself an extension from the prototypical referential use;

(ii) the intersubjective uses (mitigation, commercial use and hypocoristic use) are direct extensions from the referential use; 
(iii) the use of thwarted imminence ( $\beta$ ) with 'fake' tense and/or aspect extends from the use of thwarted imminence $(\alpha)$ with 'real' tense and aspect which itself extends either from the de conatu use - as a specific instance of the imperfective paradox, i.e., with telic predicates - or from the referential use - with atelic predicates (see sections 5.2.2.1 and 5.3.2.2).

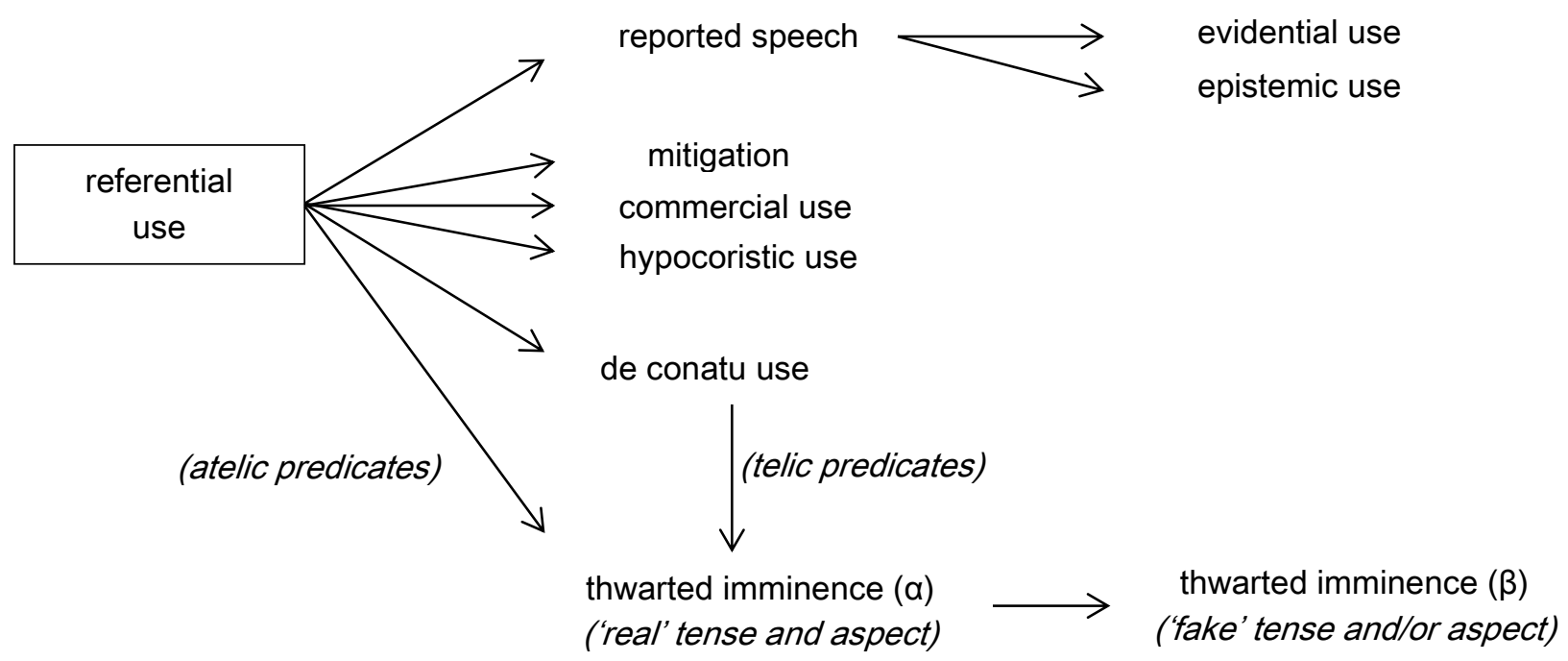

Figure 9. The modal uses of past tenses: paths of semantic change

These paths of development permit us to make two typological predictions about the modal uses exhibited by past tenses in natural languages. These predictions can be formulated as implicational hierarchies: in one given language,

(i) the presence of the evidential and epistemic uses implies the presence of the reported speech use;

(ii) the presence of the use of thwarted imminence with fake tense and/or aspect implies the presence of the de conatu use, i.e., the imperfective paradox (hence the absence of thwarted imminence with fake tense and/or aspect in Germanic languages).

It will be the task of future studies to validate and/or complete these implicational hierarchies.

\section{Concluding remarks}

The aim of this paper was to offer a unified account of the modal interpretations of past tenses that takes into consideration the semantic contribution of both tense and aspect. To address the issue, I proposed a formal system (section 2) in which I defend an aspecto-temporal conception of past tenses based on the notion of reference point $(\mathrm{R})$ and their different interpretations (including the modal ones) are taken to manifest specific instantiations of $\mathrm{R}$ (as 'topic time', 'aspectual vantage point' and/or 'epistemic evaluation'). I have further examined data from six European (Romance and Germanic) languages and elaborated a description and classification of the modal uses resting on semantic criteria and tests (section 4). On the basis of the given classification, I finally suggested to view modal uses of past tenses as invited inferences (notably scalar implicatures) reflecting different stages of a semantic evolution (section 5).

The proposed analysis permits us to address the questions raised in the introduction. It first shows that the modal domain covered by imperfects and preterits in the languages under scrutiny includes three main categories of meaning: epistemicity (uncertain realisation, non-realisation and inactuality), evidentiality (indirect evidence), intersubjectivity (politeness and empathy). The analysis also clarifies 
the respective contribution of (past) tense and (imperfective/neutral) aspect in the interpretation of modality: while both components are required to produce modality in most uses by allowing modal implicatures, the interpretation of counterfactuality, i.e., the non-realisation of the eventuality, crucially relies on imperfective aspect. This fact explains why preterits in the Germanic languages under investigation do not exhibit the de conatu use, and why the use of thwarted imminence remains marginal in those languages. Finally, the dynamic perspective I have adopted permits one to trace the pragmatic origin of the modal interpretations at the incipient stage of 'bridging contexts' and follow up their further conventionalisation at the expense of the source meaning in the more advanced stage of 'switch contexts'. This analysis helps pinpointing why tense and aspect are fake in certain uses: the past tense no longer refers to a past topic time or a viewpoint on the eventuality (tense and aspect are then 'real') but only refers to the epistemic evaluation of the proposition. In other words, the past tense does not scope anymore over the eventuality but over its epistemic validity, this scopal swing being the result of the conventionalisation of Gricean modal implicatures.

Ultimately, the study suggests that modal uses corresponding to switch contexts may not be connected anymore to the schematic meaning of past tenses in the cognitive system of speakers. They would rather constitute independent uses in which the modal implicatures attached to the past tense cannot be separated from the contexts (or 'constructions') where they arise. One could then talk about 'pragmatic polysemy' in that the polysemy of past tenses is not coded in the linguistic system but stems from different contextual implicatures that conventionalise in particular constructions.

\section{References}

Adam, Jean-Michel, 1992. Si hypothétique et l'imparfait. Une approche linguistique de la fictionalité. Etudes littéraires (25/1-2), 147-166.

Anderson, Alan Ross 1951. A Note on Subjunctive and Counterfactual Conditionals, Analysis (12), 35-38

Antinucci, Francesco, Miller, Ruth, 1976. How children talk about what happened. Journal of Child Language (3), 167-189.

Anderson, Alan Ross, 1951. A Note on Subjunctive and Counterfactual Conditionals. Analysis (11), 35-38.

Arregui, Ana Cristina, 2005, On the accessibility of possible worlds: the role of tense and aspect, Doctoral dissertation. University of Massachusetts, Amherst (USA).

Arregui, Ana Cristina, 2007, When aspect matters: the case of "would" conditionals. Natural Language Semantics (15), 221-264.

Arregui, Ana, 2009, On similarity in counterfactuals. Linguistics and Philosophy (32/3), 245-278.

Barceló, Gérard Joan, Bres, Jacques, 2006. Les temps de l'indicatif en français. Paris, Ophrys.

Bazanella, Carla, 1990. 'Modal' uses of the Italian Indicative Imperfetto in a Pragmatic perspective. Journal of Pragmatics (14/3), 439-457.

Heine, Bernd, 2002. On the Role of Contexts in Grammaticalization. In: Wischer, I., Diewald, G. (Eds.), New reflections on grammaticalization. Amsterdam, John Benjamins, pp. 83-101.

Berthonneau, Anne-Marie, Kleiber, Georges, 1994. Imparfait et politesse : rupture ou cohésion ?. Travaux de linguistique (29), 59-92.

Berthonneau, Anne-Marie, Kleiber, Georges, 2003. Un imparfait de plus ... et le train déraillait. Cahiers Chronos (11), 1-24.

Berthonneau, Anne-Marie, Kleiber, Georges, 2006. Sur l'imparfait contrefactuel. Travaux de linguistique (53/2), 7-65.

Bertinetto, Pier Marco, 1986. Tempo, aspetto e azione nel verbbo italiano. Il sistema dell'indicativo. Firenze, Accademia della Crusca. 
Boogaart, Ronny, Trnavac, Radoslava, 2011. Imperfective aspect and epistemic modality. In: Patard, A., Brisard, F. (Eds.), Cognitive Approaches to Tense, Aspect, and Epistemic Modality. Amstderdam, John Benjamins, pp. 217-248.

Bres, Jacques, 2006. « Encore un peu, et l'imparfait était un mode. . . » L'imparfait et la valeur modale de contrefactualité. Cahiers de praxématique (47), 149-176.

Bres, Jacques, 2009. Sans l'imparfait, les vendanges tardives ne rentraient pas dans la jupe rhénane... Sur l'imparfait contrefactuel, pour avancer, Syntaxe et sémantique (10), 33-50.

Brisard, Frank, 2010. Aspects of virtuality in the meaning of the French imparfait. Linguistics (48/2), 487-524.

Briz Gómez, Emilio Antonio, 2004, Notas sobre los llamados usos temporales "dislocados" en la conversación coloquial. Estudios de Lingüística (2), 43-53.

Brown, Penelope, Levinson, Stephen C., 1987. Politeness: some universals in language usage. Cambridge, Cambridge University Press.

Caudal, Patrick. 2011, Towards a novel aspectuo-temporal account of conditionals. Cahiers Chronos 22, 179-209.

Caudal, Patrick, Vetters, Carl, Roussarie, Laurent, 2003. L'imparfait, un temps inconséquent. Langue française (138), 61-74.

Comrie, Bernard, 1985. Tense. Cambridge: Cambridge University press.

Cutrer, Michelle, 1994. Time and tense in narrative and everyday language. Doctoral Dissertation, University of California, San Diego (U.S.).

Dahl, Östen, 1997. The relation between past time reference and counterfactuality: a new look. In: Athanasiadou, A., Dirven, R. (Eds.), On conditionals again. Amsterdam, John Benjamins, pp. 97-114.

Damourette, Jacques, Pichon, Édouard, 1911-1936/1970. Des mots à la pensée (vol. 5). Paris, D'Artrey.

Dancygier, Barbara, Eve Sweetser, 2005. Mental spaces in grammar. Cambridge, Cambridge University Press.

De Mulder, Walter, 2004. Can there be a non temporal definition of the French Imparfait ? A "network" approach. In: Brisard, F. (Ed.), Language and revolution / Language and time. Antwerpen, Universiteit Antwerpen, pp. 195-222.

De Mulder, Walter, Brisard, Frank, 2006. L'imparfait marqueur de réalité virtuelle. Cahiers de praxématique (47), 97-124.

De Wit, Astrid, Patard, Adeline, 2013. Modality, aspect and the progressive. The semantics of the present progressive in French, in comparison with English. Languages in Contrast (13.1), 113132.

Doiz Bienzobas, Aintzane, 2002. The preterit and the imperfect as grounding predications. In: Brisard, F. (Ed.), Grounding. The epistemic footing of deixis and reference. Berlin, Mouton de Gruyter, pp. 299-347.

Dowty, David R. 1979, Word meaning and Montague Grammar: The semantics of verbs and times in Generative Semantics and Montague's PTQ. Kluwer, Dordrecht.

Fauconnier, Gilles, 1994. Mental spaces. Cambridge, Cambridge University Press.

Fayol, Michel, 1985. L'emploi des temps verbaux dans les récits écrits. Etudes chez l'enfant, l'adulte et l'adolescent. Bulletin de Psychologie (XXXVIII.7), 683-704.

Ferraro, Marta Iglesis, López, Jorge Fernando Ortiz, 2002. La temporalidad verbal en español. In: Proceedings of the 2. Congreso Brasileño de Hispanistas. San Pablo, São Paulo. Available from: http://www.proceedings.scielo.br/scielo.phpscript=sci arttextandpid=MSC00000000120020001 00038andlng=enandnrm=iso $>$. 
Fleischman, Suzanne, 1989. Temporal distance: A basic linguistic metaphor. Studies in Language (13), 1-50.

Fleischman, Suzanne, 1995. Imperfective and irrealis. In: Bybee, J., Fleischman, S. (Eds.), Modality in grammar and discourse. Amsterdam/Philadelphia, John Benjamins, pp. 519-551.

García Fernández, Luis, 2004. El pretérito imperfecto: repaso histórico y bibliográfico. In: García Fernández, Luis, Camus Bergareche, Bruno (Eds.), El pretérito imperfecto. Madrid, Gredos, pp. 14-95.

Gosselin, Laurent. 1999. Les valeurs de l'imparfait et du conditionnel dans les systèmes hypothétiques. Cahiers Chronos (4), 29-51.

Givón, Talmy, 1994. Irrealis and the subjunctive. Studies in Language (18), 265-337.

Gosselin, Laurent. 1996, Sémantique de la temporalité en français. Un modèle calculatoire et cognitif du temps et de l'aspect. Duculot, Louvain-la-Neuve.

Gosselin, Laurent, 2010. Les modalités en français: la validation des représentations, Amsterdam, Rodopi.

Grice, Paul H., 1975, Logic and conversation. In: Cole, P., Morgan, J. L. (Eds.), Speech Acts. New York, Academic Press, pp. 41-58.

Hopper, Paul J., 1979. Some observations on the typology of focus and aspect in narrative language. Studies in Language (6/3), 375-403.

Iatridou, Sabine, 2000. The Grammatical Ingredients of Counterfactuality. Linguistic inquiry (31), 231-270.

Imbs, Paul, 1960. L'emploi des temps verbaux en français moderne. Paris, Klincksieck.

Ippolito, Michela, 2003. Presupposition and implicatures in counterfactuals. Natural Language Semantics (11/2), 145-186.

Ippolito, Michela, 2004. Imperfect Modality. In: Guéron, J., Lecarme, J. (Eds.), The Syntax of Time. Cambridge, MIT Press, 359-387.

James, Deborah, 1982. Past tense and the hypothetical. A cross-linguistic study. Studies in Language (6), 375-403.

Janssen, Theo A.J.M., 1994. Preterit and Perfect in Dutch. In Vet, C., Vetters, C. (Eds.), Tense and Aspect in Discourse. Berlin, Mouton de Gruyter, pp. 115-146.

Jaszczolt, Katarzyna, Srioutai, Jiranthara, 2011. Communicating about the past through modality in English and Thai. In: Patard, A., Brisard, F. (Eds.), Cognitive Approaches to Tense, Aspect, and Epistemic Modality. Amstderdam, John Benjamins, pp. 249-278.

Klein, Wolfgang, 1994. Time in language. Routledge, London \& New York.

Langacker, Ronald W., 1978. The form and the meaning of the English auxiliaries. Language (54), 853-882.

Langacker, Ronald. W., 1987. Foundations of Cognitive Grammar: Theoretical Prerequisites, Stanford: Stanford University Press.

Langacker, Ronald W., 1991. The Auxiliary: Grounding. In: Foundations of Cognitive Grammar (vol. 2). Stanford, Stanford University Press, pp. 240-281.

Le Goffic, Pierre, 1986. Que l'imparfait n'est pas un temps du passé. In: Le Goffic, P. (Ed.), Points de vue sur l'imparfait. Caen, Centre de publications de l'université de Caen, pp. 55-70.

Le Goffic, Pierre, 1995, La double incomplétude de l'imparfait, Modèles linguistiques (16), 133-148.

Leonetti, Manuel, Escandell-Vidal, Victoria, 2003. On the Quotative readings of Spanish Imperfecto. Cuadernos de Lingüística (X), 135-154.

Lyons, John, 1977. Semantics. Cambridge, Cambridge University Press.

Martin, Robert, 1991. Types de procès et systèmes hypothétiques; de l'aspect 'de re' à l'aspect 'de dicto'. Travaux de linguistique et de philologie (22), 87-95. 
Mellet, Sylvie, 1988. L'imparfait de l'indicatif en latin classique. Temps, aspect, modalité. Leuven, Peeters.

Mellet, Sylvie, 1990. Temps et mode en latin: à propos de l'imparfait. Bulletin de la Société de Linguistique de Paris (LXXXV), 161-171.

Palmer, Frank, 1986. Mood and Modality. Cambridge, Cambridge University Press.

Patard, Adeline, 2007. L'un et le multiple. L'imparfait de l'indicatif en français: valeur en langue et usages en discours, Doctoral dissertation. University of Paul-Valéry, Montpellier (France).

Patard, Adeline, 2011. The epistemic uses of the English simple past and French imparfait, In: Patard,

A., Brisard, F. (Eds.), Cognitive Approaches to Tense, Aspect, and Epistemic Modality. Amstderdam, John Benjamins, pp. 279-310.

Patard, Adeline, Richard, Arnaud, 2011. Attenuation in French simple tenses. Cahiers Chronos (22), 179-209.

Patard, Adeline, De Mulder, Walter, 2014. Aux origines des emplois modaux de l'imparfait: Le cas de l'emploi hypothétique et de l'emploi contrefactuel. Langages (193), 33-47.

Reichenbach, Hans, 1947. Elements of Symbolic Logic. New York: Free Press.

Schmid, Sarah Dessi, 2010. 'Modal uses' of the Italian imperfetto and the Spanish imperfecto: a comparison. In: Becker, M. G., Remberger, E.-M. (Eds.), Modality and Mood in Romance. Berlin, De Gruyter, pp. 39-66.

Squartini, Mario, 1995. Tense and Aspect in Italian. In: Thieroff, R. (Ed.), Tense Systems in European Languages II. Tübingen, Niemeyer, pp. 117-134.

Squartini, Mario, 2001. The internal structure of Evidentiality in Romance. Studies in language (25/2), 297-334.

Stalnaker, Robert 1975. Indicative conditionals. In: Kasher, A. (Ed.). Language in Focus: Foundations Methods and Systems. Reidel, Dordrecht, pp. 179-96.

Tedeschi, Philip J., 1981. Some evidence for a branching-futures semantic model. In: Tedeschi, Z., Zaenen, Annie, (Eds.). Tense and aspect (volume 14 of Syntax and Semantics). New York, Academic Press, pp. 239-270.

Thieroff, Rolf, 1994. Inherent verb categories and categorizations in European languages. In: Thieroff, R., Ballweg, J. (Eds.), Tense systems in European languages. Tübingen, Niemeyer, pp. 3-45.

Thieroff, Rolf, 1995. More on inherent verb categories in European languages. In: Thieroff, R. (Ed.), Tense Systems in European Languages II. Tübingen, Niemeyer, pp. 1-36.

Thieroff, Rolf, 1999. Preterites and imperfects in the languages of Europe. In: Abraham, W., Kulikov, L. (Eds.), Tense-Aspect, Transitivity and Causativity. Amsterdam/Philadelphia, John Benjamins, pp. 141-161.

Touratier, Christian, 1996. Le système verbal français. Paris, Armand Colin.

Traugott, Elizabeth Closs, Heine, Bernd (Eds.). 1991. Approaches to Grammaticalization: Volume II. Types of grammatical markers. John Benjamins Publishing, Amsterdam.

Traugott, Elizabeth Closs, Dasher, Richard B., 2002. Regularity in Semantic Change. Cambridge, Cambridge University Press.

Vairel, Hélène, 1982. Les phrases conditionnelles/hypothétiques en français: la valeur de si A, B. L'information grammaticale (14), 5-10.

van der Auwera, Johan, Plungian, Vladimir A., 1998. Modality's semantic map. Linguistic Typology (2), 79-124.

Van linden, An, Verstraete, Jean-Christophe, 2008. The nature and origins of counterfactuality in simple clauses. Cross-linguistic evidence. Journal of Pragmatics (40), 1865-1895.

Verstraete, Jean-Christophe, 2006. The nature of irreality in the past domain: evidence from past intentional constructions in Australian languages. Australian Journal of Linguistics (26/1), 5979. 
Wunderlich, Dieter, 1970. Tempus und Zeitreferenz im Deutschen. Munich, Max Hueber.

Ziegeler, Debra, 2000. Hypothetical Modality. Grammaticalisation in an L2 Dialect. Amsterdam and Philadelphia, John Benjamins.

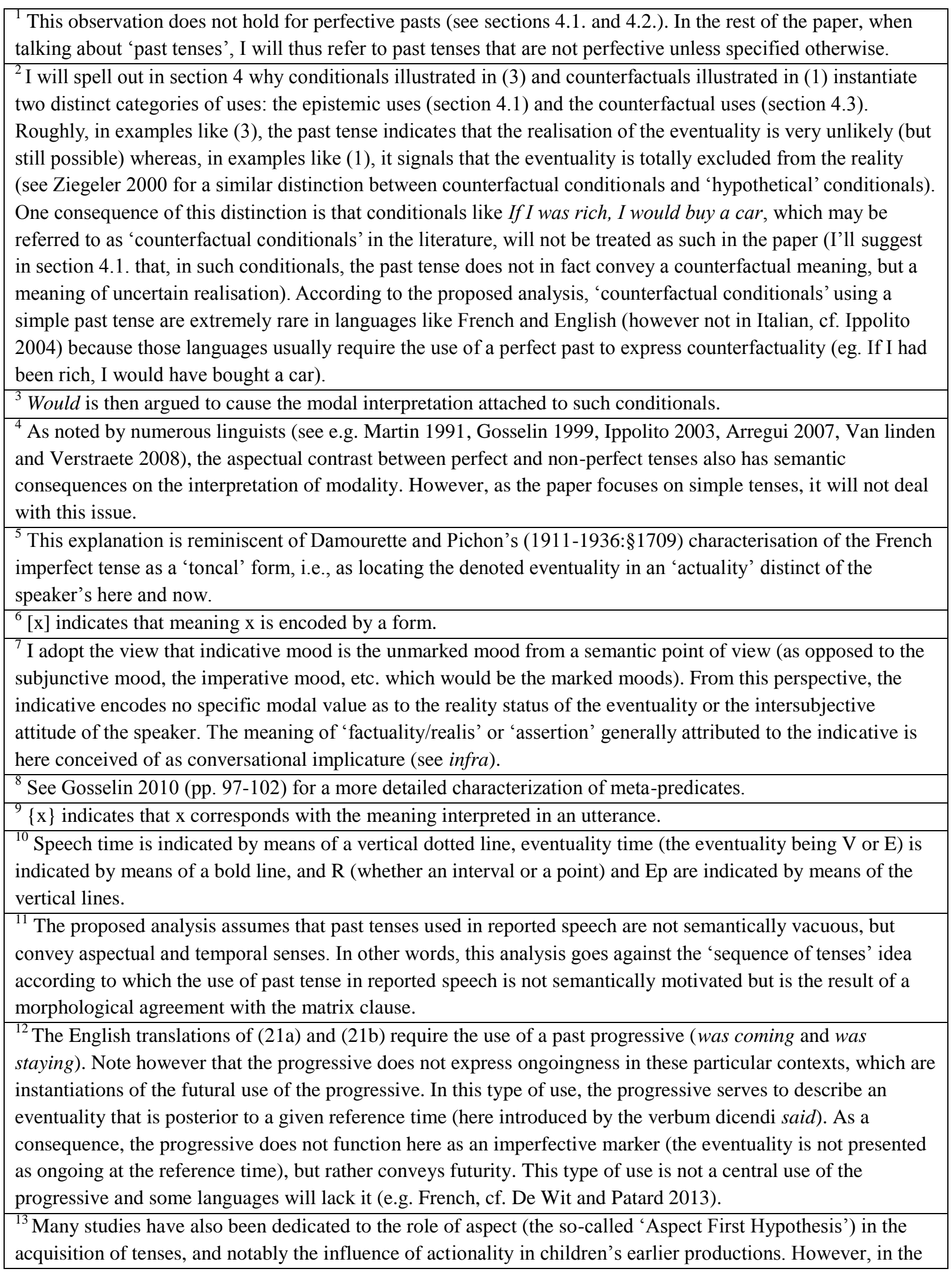


case of preludic contexts, actionality does not seem to determine the choice of the tense morpheme which can indiscriminately apply to telic or atelic predicates (see section 4.5).

${ }^{14}$ By sake of convenience, I include the evidential uses within the modal uses because evidentiality is generally combined with additional epistemic nuances in these uses (see section 4.2). However, I am not taking part in the longstanding debate about whether evidentiality is in fact a modal category.

${ }^{15}$ See Martin 1991, Gosselin 1999, Arregui 2007 for different accounts of these contextual elements.

${ }^{16}$ The sense of deontic necessity attached to the hortative example in (34) is not an inference based on the epistemic interpretation of the simple past but comes from the phrase high time. High time indeed specifies the "ethical norm(s) [...] obliging the participant to engage in the state of affairs" (van der Auwera \& Plungian 1998: 81), namely that the hearers should go to bed because it is required by the late hour.

${ }^{17}$ See Squartini (2001) and Leonetti and Escandell-Vidal (2003) for detailed analyses of these uses in Romance languages.

${ }^{18}$ The progressive in the English translation ('was arriving') does not function here as an imperfective marker but rather conveys futurity (see footnote 12 ).

${ }^{19}$ See figure 4 for an illustration of the propositional-external scope of past tenses in evidential uses.

${ }^{20}$ The de conatu use is not attested in the Germanic languages. Indeed, the preterit cannot normally be used alone in this type of use, but generally requires progressive periphrasis, as exemplified in:

An Indian prince, who was very fond of going on the water, had one day the misfortune to fall into a river; he was drowning (/ *drowned), when a slave plunged in, caught him by the hair of his head, dragged him to the shore, and saved his life. (J.M. Lainé, The danger of being ungrateful)

As for the counterfactual use, it is attested in the three Germanic languages under investigation, but it is restricted to atelic predicates (cf. example (41)).

${ }^{21}$ This terminology (found for instance in Bertinetto 1986) seems inadequate in that the utterance does not always describe an attempt from an animate subject. However, for the sake of convenience, I keep the traditional term de conatu.

${ }^{22}$ This is the translation of 'imminence contrecarrée' usually found in the Francophone literature. However this terminology is not fully appropriate insofar as the described eventuality is not always imminent with regard to the adopted reference point. However, for sake of convenience, I keep using the commonly-used term 'thwarted imminence'.

${ }^{23}$ In contrast, an imperfective past entails that the eventuality did occur with an atelic predicates (Max was running $\rightarrow$ Max ran).

${ }^{24}$ When the telic predicates refers to an achievement (e.g. salir 'leave' in (39)), the punctual duration of the eventuality seems to be extended by virtue of the use of an imperfect so that imperfective aspect can be said to coerce a punctual eventuality into a durative one.

${ }^{25}$ This use may also be found in the speech of adults pretending that a eventuality is the case in an imaginary world. However, in such cases, the speaker's communicative intention is to mimic the speech of children and to give a childish colour to her own speech.

${ }^{26}$ This is quite surprising given that, from an early age, young children show a strong tendency to use imperfects to describe durative eventualities (see for instance Fayol 1985 for French, Antinucci and Miller 1976 for Italian). But this generalisation does not seem to hold for preludic contexts.

${ }^{27}$ Ippolito remarks for Italian (2004:40) that the counterfactual interpretation of the imperfect in subjunctive conditionals (i.e. what I call the use of thwarted imminence) resists cancellability mcuh more than its modal interpretation in standard subjunctive conditionals (i.e. in hypotheticals). This could suggest that modality in contexts of thwarted imminence is more conventionalised than in hypothetical conditionals.

${ }^{28}$ In the case of past tenses, other possible weak scalar implicatures are evidential ones - the speaker implicates that she has no direct evidence for the denoted state of affairs (see 5.2.2.1.) - and interpersonal ones - the speaker implicates an attitude of politeness or empathy towards the hearer (see 5.2.2.2.).

${ }^{29}$ See Berthonneau and Kleiber 2003 and 2006, and Bres 2006 and 2009 for a detailed analysis of these two elements: the bipartite structure [p, (et) q] and the initial counterfactual component $p$.

${ }^{30}$ Diachronic data from French and Latin (cf. Patard and De Mulder 2014) suggest that the use of thwarted 
imminence may have developed from a specific type of counterfactual conditionals using a subjunctive form in the protasis and an indicative past tense in the apodosis.

${ }^{31}$ The idea that counterfactual interpretations involve a past moment when the eventuality's realisation was still conceivable echoes Tedeschi's analysis of counterfactual conditionals based on a branching-futures model. Indeed Tedeschi explains (1981:256) that "we evaluate counterfactual conditional sentences as if we returned to the past and looked at possible futures with respect to that past". My analysis further converges with Dahl's observation (1997:107) that counterfactuality always involves some past 'choice point', i.e., a past moment when 'the choice between what actually happened and what could have happened was made'.

${ }^{32}$ This analysis in terms of switch context seems to be confirmed by diachronic data concerning the evolution of conditionals in Germanic languages (cf. Dahl 1997) and Latin (cf. Patard and De Mulder 2014): it seems that, in those languages, the past sense originally attached to hypothetical and counterfactual conditionals has been overshadowed by modal meanings conveyed in such contexts.

${ }^{33}$ This hypothesis converges with Ziegeler's analysis that (2000) epistemic implicatures in conditionals proceed from the combination of past time reference and meanings of prediction or volition. In my view, utterances expressing past predictions or volitions (such as reported speech involving telic predicates) favour epistemic implicatures because they suppose a temporal dissociation between the time of the eventuality (E) and the time of its epistemic validity (V); as a result, the past tense can only refer to the past epistemic evaluation of the eventuality (and not to the eventuality), which may generate an epistemic implicature. However, my analysis differs from that of Ziegeler on the following point: it is crucially the interpretation of $\mathbf{R}$ as past Ep that allows for the epistemic implicature; this interpretation indeed permits the speaker to imply that he refuses to vouch for the eventuality's validity in the present and hence that is doubting about its factual realisation. 